NASA TECHNICAL NOTE

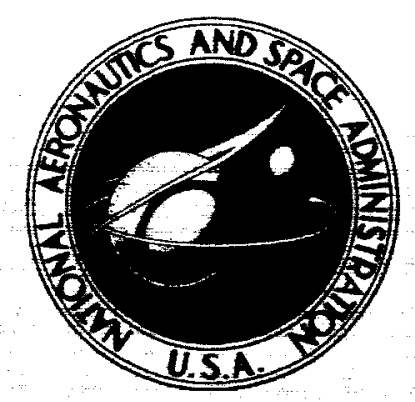

NASA TN D-7838

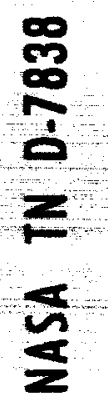

$c$

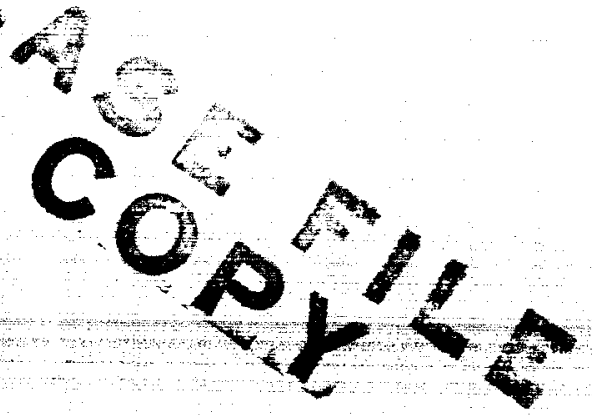

EFFECTS OF ALLOY COMPOSITION IN

ALLEVIATING EMBRITTLEMENT PROBLEMS

ASSOCIATED WITH THE TANTALUM ALLOY T-111

Joseph R. Stephens

Lewis Research Center

Cleveland, Obio 44135

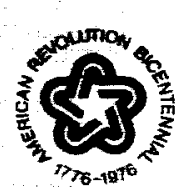

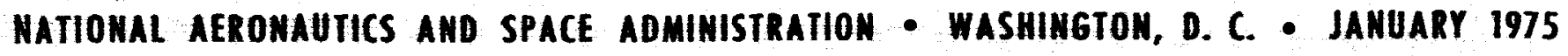




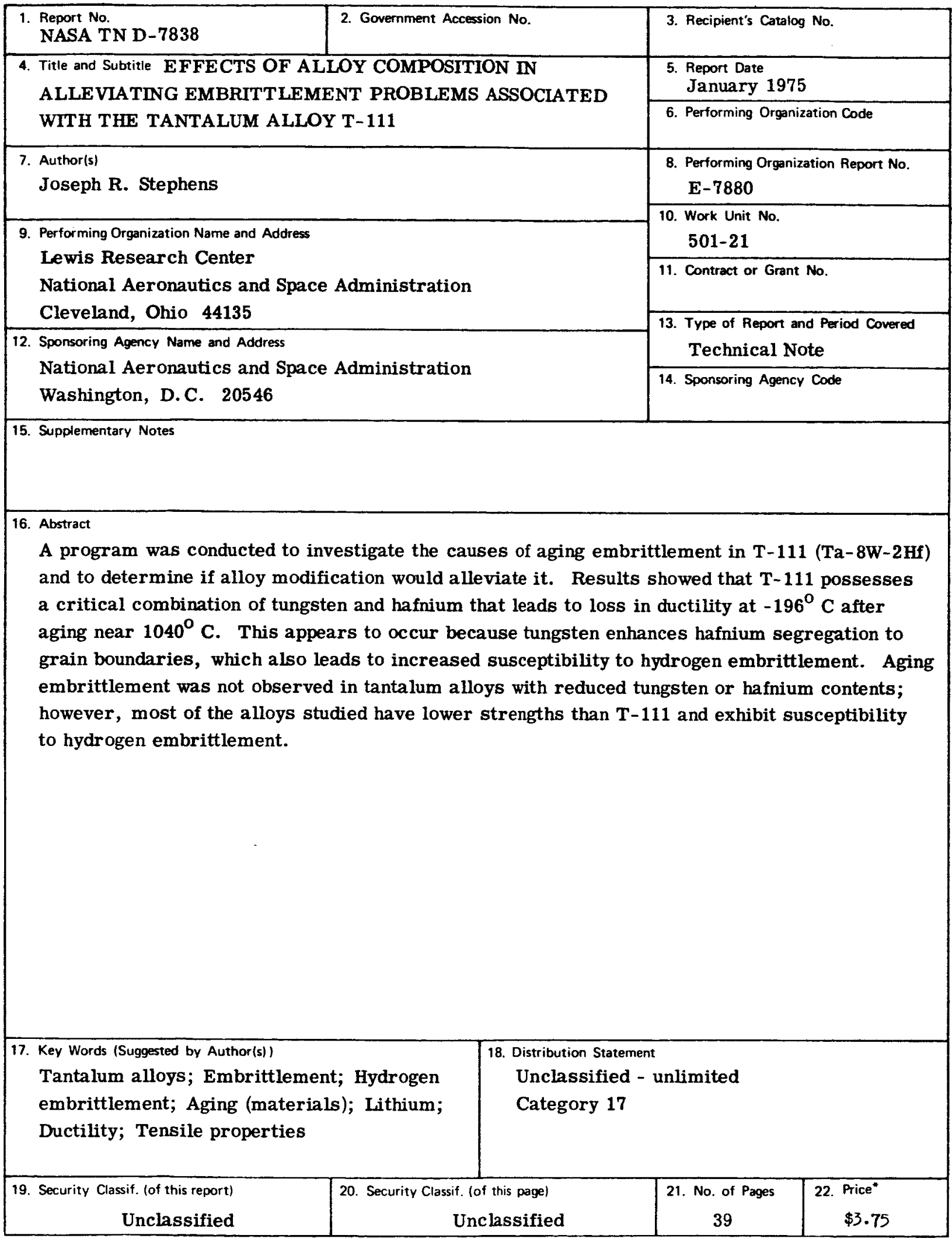

* For sale by the National Technical Information Service, Springfield, Virginia 22151 
Page

SUMMARY . . . . . . . . . . . . . . . . . . . . . . . . . . . 1

INTRODUCTION . . . . . . . . . . . . . . . . . . . . . . . 2

EXPERIMENTAL . . . . . . . . . . . . . . . . . . . . . . 3

Materials .. . . . . . . . . . . . . . . . . . . . 3

Aging . . . . . . . . . . . . . . . . . . . . . . . . . . . . 4 4

Hydrogen Doping . . . . . . . . . . . . . . . . . . . . . . . 5

Evaluation ............................... . 5

Bend tests . . . . . . . . . . . . . . . . . . . . . 5

Tensile tests . . . . . . . . . . . . . . . . . . . . . . . 5

Metallography and chemical analyses . . . . . . . . . . . . . . . 5

RESULTS . . . . . . . . . . . . . . . . . . . . . . . . . 6

Chemical Analysis . . . . . . . . . . . . . . . . . . . . . 6

Bend Ductility of $\mathrm{T}-111$. . . . . . . . . . . . . . . . . . . . 6

Effects of processing history . . . . . . . . . . . . . . . . . 7

Effects of pre-age annealing temperature . . . . . . . . . . . . . 7

Effects of aging conditions . . . . . . . . . . . . . . . . . 7

Effects of welding-sheet . . . . . . . . . . . . . . . . . . . . . 8

Effects of hydrogen doping . . . . . . . . . . . . . . . . . . 8

Bend Ductility of Other Tantalum Alloys . . . . . . . . . . . . . . . . . . 9

Effects of composition on aging embrittlement . . . . . . . . . . . . . . . 9

Effects of composition on hydrogen embrittlement . . . . . . . . . . . . . 9

Tensile Properties of Ta Alloys . . . . . . . . . . . . . . . . . . . . 10

Tensile strength of $\mathrm{T}-111$. . . . . . . . . . . . . . . . . . . . . . 10

Tensile strength of other Ta alloys . . . . . . . . . . . . . . . . . . 11

Scanning Electron Microscopy Examination . . . . . . . . . . . . . . . . 11

DISCUSSION . . . . . . . . . . . . . . . . . . . . . . . . . 13

Ductility Effects . . . . . . . . . . . . . . . . . . . . . . 13

Strength Effects . . . . . . . . . . . . . . . . . . . . . . . . 14

Applicability of Results to Alloy Selection . . . . . . . . . . . . . . . . 14

CONCLUSIONS . . . . . . . . . . . . . . . . . . . . . . . . 15

REFERENCES . . . . . . . . . . . . . . . . . . . . . . 16 


\section{EFFECTS OF ALLOY COMPOSITION IN ALLEVIATING EMBRITTLEMENT \\ PROBLEMS ASSOCIATED WITH THE TANTALUM ALLOY T-11l}

by Joseph R. Stephens

Lewis Research Center

\section{SUMMARY}

A program was conducted to determine effects of modifying the composition of T-111 (Ta-8W-2Hf) to alleviate problems associated with aging embrittlement and susceptibility to hydrogen embrittlement after long-term aging near $1040^{\circ} \mathrm{C}$. In addition to the effects of alloy composition, effects of pre-age annealing temperature, aging time, temperature, and environment (lithium or vacuum), welding, and hydrogen doping were also investigated for eight tantalum-base alloys. Bend testing at $-196^{\circ}$ and $25^{\circ} \mathrm{C}$ was used to determine the extent of embrittlement of the alloys, and tensile testing over the temperature range $25^{\circ}$ to $1180^{\circ} \mathrm{C}$ was used to determine changes in strength after longterm aging.

The results showed that aging Ta-8W-2Hf (T-111) and Ta-8W-3Hf at $1040^{\circ} \mathrm{C}$ resulted in a loss in ductility (aging embrittlement) upon bend testing at $-196^{\circ} \mathrm{C}$. Reducing either the tungsten or hafnium contents of these alloys by 50 percent circumvented aging embrittlement. Also, aging at $1040^{\circ} \mathrm{C}$ for long times increased the susceptibility to hydrogen embrittlement of all ternary and more complex alloys; binary alloys Ta-10W and Ta-2Hf exhibited no such increase.

Scanning electron micrographs showed that hafnium-rich particles formed at grain boundaries of ternary alloys during long-term aging at $1040^{\circ} \mathrm{C}$; binary alloys were free of these precipitate particles after similar aging. These particles are believed to be responsible for the aging embrittlement and increased susceptibility to hydrogen embrittlement of ternary alloys.

Tensile test results indicated that the major effect of long-term aging was to reduce the dynamic strain-age strengthening observed in annealed $\mathrm{T}-111$ over the temperature range $600^{\circ}$ to $1040^{\circ} \mathrm{C}$. In addition, reducing either the tungsten or hafnium contents of T-111 by 50 percent to prevent aging embrittlement resulted in a 25 to 40 percent reduction in strength at $1040^{\circ} \mathrm{C}$. 


\section{INTRODUCTION}

Tantalum alloys have been considered for use in advanced space-power systems in applications such as nuclear fuel-element cladding and liquid alkali metal containment. Minimum requirements for these applications include high creep resistance in the temperature range $980^{\circ}$ to $1300^{\circ} \mathrm{C}$, a ductile-brittle transition temperature well below room temperature, good formability and weldability, and corrosion resistance to liquid alkali metals such as lithium and potassium. Results have shown that severe corrosion can occur in tantalum - 10-tungsten ( Ta-10 W $)^{1}$ contaminated with oxygen concentrated at grain boundaries, because of the preferential attack of these high-oxygen-content regions by liquid metals such as sodium or potassium. Because of this potential corrosion problem, a reactive element such as hafnium is added to the Ta-base alloy to serve as a getter for oxygen. The stable oxide that forms, hafnium dioxide $\left(\mathrm{HfO}_{2}\right)$, is not attacked by the alkali metal thus permitting operation of Ta-base alloys in alkali metal environments even when oxygen contamination exists. Tests have shown that T-111 (Ta-8W-2Hf) can successfully operate for several thousand hours in an alkali metal environment with little or no corrosion (ref. 1).

Because of its good corrosion resistance and fabricability, T-111 has become the prime structural material for several space-power system applications. However, isolated instances of cracking during fabricating and processing have been reported (ref. 2). In addition, room-temperature embrittlement has been noted in specimens aged for 1000 hours or longer at temperatures near $1000^{\circ} \mathrm{C}$, a proposed usetemperature for the alloy in some systems (refs. 3 and 4). More recently, Watson and Stephens (ref. 5) conducted a program to determine the probable causes of the postaging embrittlement of $\mathrm{T}-111$. The results of their study indicated that the brittle, intergranular fractures observed in aged $\mathrm{T}-111$ were caused by hydrogen embrittlement during post-aging handling operations. Aging at $1040^{\circ} \mathrm{C}$ for long periods of time greatly increased the sensitivity of $\mathrm{T}-111$ to hydrogen embrittlement. Metallographic studies showed that T-111 aged at $1040^{\circ} \mathrm{C}$ contained numerous $\mathrm{HfO}_{2}$ particles located primarily at grain boundaries and exhibited brittle, intergranular failure. In contrast, material that had been aged at a higher temperature $\left(1315^{\circ} \mathrm{C}\right)$ was free of precipitate particles and exhibited ductile behavior. The results from their study thus suggest that the presence of $\mathrm{HfO}_{2}$ at the grain boundaries of T-111 aged at $1040^{\circ} \mathrm{C}$ may be associated with its subsequent increased sensitivity to hydrogen embrittlement.

The primary purposes of the present investigation were to investigate in greater depth the causes of embrittlement observed in T-111 after long-term aging and to seek means of alleviating this problem through alloy modification. In conducting this experimental program, a standard aging treatment of 1000 hours at $1040^{\circ} \mathrm{C}$ (in lithium or in

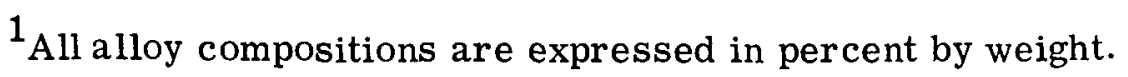


vacuum) was used. In studying the causes of T-111 embrittlement, emphasis was directed at defining the particular material and aging conditions that promote embrittlement. This included a study of the effects of variation in fabrication history (sheet or tube), pre-age annealing temperature (to achieve different grain sizes), simulated butt welding, and aging conditions (time, temperature, and environment). Tests were also directed toward determining if hydrogen contamination is a necessary step in the embrittlement process. In seeking a means of alleviating the embrittlement problem, the effects of modifying the Hf or $\mathrm{W}$ contents of $\mathrm{T}-111$ were evaluated. This was accomplished by conducting aging tests on seven other alloys with compositions similar to that of T-111. The primary method of determining the effects of these variables on ductility was by bend testing at $25^{\circ}$ and $-196^{\circ} \mathrm{C}$. Also, tensile tests were conducted over the temperature range $25^{\circ}$ to $1180^{\circ} \mathrm{C}$, to determine the effects of the variables on strength. Fractured specimens were examined by scanning electron microscopy (SEM) to ascertain the cause of brittle failure.

\section{EXPERIMENTAL}

The flow diagrams shown in figure 1 summarize the test program which was conducted in two parts: One involved only T-111 and was an in-depth study of variables that might contribute to embrittlement of this alloy. The other involved seven additional Ta alloys and was conducted to evaluate the effects of alloy composition in alleviating the T-111 embrittlement problem. The following sections describe the specific materials and experimental procedures used in these studies.

\section{Materials}

Table I gives the chemical analyses of the eight Ta-base alloys investigated in this program. All of these alloys were procured from a commercial vendor who used standard practices of the production of Ta-alloy sheet and tube. Two of the alloys ( $\mathrm{T}-111$ and $\mathrm{Ta}-10 \mathrm{~W})$ are commercially available; five of the other alloys are experimental with compositions selected to evaluate the effects of variations in $\mathrm{W}$ and Hf contents. ASTAR-811C was added in the latter stages of the program and only underwent a cursory evaluation. This alloy is a stronger, carbon-bearing alloy of the T-111 family. The primary alloy under investigation, $T-111$, was produced as 1.5 -millimeter-thick sheet and also as tubing having a 19 millimeter outside diameter and a 1.5 millimeter wall thickness. The other three alloys, Ta-10W and ASTAR-811C, and an experimental Ta-2Hf alloy were in the form of 0.8-millimeter thick sheet; the remaining four experimental alloys were obtained in the form of 1.0 millimeter thick sheet. 
thick sheet; the remaining four experimental alloys were obtained in the form of 1.0 millimeter thick sheet.

Longitudinal bend specimens were cut from sheets of each of the alloys and from T-111 tubing as shown in figure 2(a) and (b). Longitudinal tensile specimens having the design shown in figure 2 (c) were cut from the sheet material, and tensile specimens having the design shown in figure $2(\mathrm{~d})$ were cut from the T-111 tubing. To evaluate the effect of welding, a gas-tungsten-arc bead-on-plate weld (to simulate a butt weld) was made along the longitudinal centerline of some of the sheet bend specimens. Welding was conducted in a chamber that had been evacuated and then back-filled with high-purity argon. A standard annealing treatment commonly used for Ta alloys consisting of 1 hour at $1650^{\circ} \mathrm{C}$ plus 1 hour at $1315^{\circ} \mathrm{C}$ was used for all the alloy specimens. In the case of welded specimens, the $1315^{\circ} \mathrm{C}$ annealing treatment followed welding.

To determine the effects of pre-age annealing temperature on subsequent susceptibility to hydrogen embrittlement, some of the T-111 specimens were annealed for 1 hour at $1815^{\circ}$ or $1980^{\circ} \mathrm{C}$ rather than $1650^{\circ} \mathrm{C}$, plus 1 hour at $1315^{\circ} \mathrm{C}$ in vacuum of $0.13 \mathrm{mi}-$ cronewtons per square meter. These annealing treatments resulted in grain sizes of 26,52 , and 150 micrometers for annealing temperatures of $1650^{\circ}, 1815^{\circ}$, and $1980^{\circ} \mathrm{C}$, respectively, as can be seen in figure 3 .

\section{Aging}

A standard aging treatment used in this study consisted of heating for 1000 hours at $1040^{\circ} \mathrm{C}$. This time-temperature combination was previously shown to cause an increased sensitivity to hydrogen embrittlement in T-111 (ref. 5). The aging treatments were conducted either in vacuum or lithium. The lithium environment was achieved by loading a bundle of tensile and bend specimens in a T-111 capsule as shown in figure 4 . After loading, the lid was welded in place using a gas-tungsten-arc weld. Lithium was then added to the capsule through a hole in the capsule lid to a depth sufficient to cover the bundle of specimens, and the capsule was sealed by electron beam welding a T-111 plug in place. Chemical analysis of the lithium showed the following impurities to be present: aluminum, $<5$ ppm; calcium, 25 ppm; copper, 5 ppm; iron, 5 ppm; magnesium, 5 ppm; silicon, 5 ppm; strontium, 25 ppm; oxygen, 77 ppm; and nitrogen, $6 \mathrm{ppm}$. Each of the eight alloys was exposed in individual capsules to prevent crossalloying effects. Similar specimens of each alloy were tied to the outside of each capsule for the vacuum exposure (fig. 4). The capsules were heated in an ultrahigh vacuum of $1.3 \times 10^{-7}$ newton per square meter for 1000 hours at $1040^{\circ} \mathrm{C}$. To study the effects of aging time and temperature on the alloy's subsequent susceptibility to hydrogen embrittlement, capsules containing T-111 specimens were also heated for 5000 hours at 
$1040^{\circ} \mathrm{C}$ to evaluate the effects of longer-aging. Other $\mathrm{T}-111$ specimens were heated for 1000 hours at $925^{\circ}$ and $1150^{\circ} \mathrm{C}$. These conditions bracket the standard aging treatment of 1000 hours at $1040^{\circ} \mathrm{C}$. Table II summarizes the annealing and aging conditions for each of the 13 capsules in the aging study.

After aging, removal of the lithium from the capsules was accomplished by vacuum distillation or by dissolution in liquid ammonia as described by Gahn (ref. 6).

\section{Hydrogen Doping}

Several specimens from each alloy that were to be doped with hydrogen were heated in an evacuated furnace to a temperature of $1040^{\circ} \mathrm{C}$, at which point hydrogen was introduced into the furnace to a pressure of 13 kilonewtons per square meter, and the specimens were held at temperature for 10 minutes followed by cooling in a helium atmosphere.

\section{Evaluation}

Bend tests. - Bend testing was conducted at temperatures of $25^{\circ}$ and $-196^{\circ} \mathrm{C}$ in a screw-driven tensile testing machine at a cross-head rate of approximately 25 millimeter per minute. A bend radius of $2 t$, where $t$ is equal to the specimen thickness, and a total bend angle of about $160^{\circ}$ were used for all tests. After completing the bend test, all the ductile specimens were flattened upon themselves with pliers at the test temperature. In effect, then, the tests were a $180^{\circ}$, ot bend. Specimens were tested in the annealed and aged conditions before and after hydrogen doping. In most cases specimens of each condition were tested at the most severe conditions $\left(-196^{\circ} \mathrm{C}\right)$. If they were brittle at this temperature, a similar specimen was then tested at $25^{\circ} \mathrm{C}$. But specimens exhibiting ductile behavior at $-196^{\circ} \mathrm{C}$ were assumed to be also ductile at the higher test temperature $\left(25^{\circ} \mathrm{C}\right)$.

Tensile tests. - Tensile testing was conducted in a screw-driven testing machine at a crosshead speed of approximately 1 millimeter per minute. Tests were conducted over the temperature range $25^{\circ}$ to $1175^{\circ} \mathrm{C}$. Tests at elevated temperatures were performed in a vacuum furnace at a pressure of approximately 7 millinewtons per square meter. The gage section of the specimens was wrapped with Ta foil to minimize contamination by residual gases in the vacuum chamber during heating.

Metallography and chemical analyses. - Specimens were examined by a standard light microscope as well as by scanning electron microscopy to characterize the alloys before and after aging. Chemical analyses were performed on selected specimens from 
each alloy before and after aging to determine changes in interstitial content resulting from long-time exposure in vacuum or lithium.

\section{RESULTS}

\section{Chemical Analysis}

Table II summarizes the oxygen and nitrogen analyses of selected specimens from both T-111 and the seven other alloys in both the annealed and aged conditions. Examination of the oxygen data reveals that aging in lithium resulted in a substantially reduced oxygen content compared with the pre-aged, annealed specimens for all of the alloys and annealing conditions studied. This reduction in oxygen content was greater for the $1040^{\circ}$ and $1150^{\circ} \mathrm{C}$ aging treatments than for the $925^{\circ} \mathrm{C}$ aging treatment. Aging in vacuum had no significant effect on the oxygen content of the Ta alloys, except for $\mathrm{T}-111$ which had been pre-age annealed at $1815^{\circ}$ and $1980^{\circ} \mathrm{C}$, where a reduction in oxygen content was observed.

From an examination of the nitrogen results, it is concluded that aging in either lithium or vacuum had no apparent effect on the nitrogen content of most of the Ta alloys. The T-111 specimens aged in lithium exhibited a large increase in nitrogen content for all of the time-temperature conditions studied. But subsequent re-evaluation of the test procedures used on those T-111 specimens indicated that nitrogen may have been introduced into the specimens during the lithium filling operation. The remaining alloys were filled with lithium in a different apparatus and were not contaminated with nitrogen. Recently, Buzzard and Metroka (ref. 7) investigated the effects of nitrogen on the mechanical properties of $T-111$. From their results one would not expect a nitrogen content of approximately $120 \mathrm{ppm}$ to have an effect on the room temperature ductility of $\mathrm{T}-111$. However, this amount of nitrogen would be expected to produce an increase in the ultimate tensile strength and yield strength of $\mathrm{T}-111$ over the temperature range used in this study, $25^{\circ}$ to $1175^{\circ} \mathrm{C}$.

Examination of the hydrogen analysis for doped specimens reveals a pickup of about 5 to $10 \mathrm{ppm}$ hydrogen for all of the alloys in the pre-age annealed condition while the aged specimens picked up from 10 to 30 ppm hydrogen.

\section{Bend Ductility of T-111}

As indicated in the flow chart shown in figure 1(a), T-111 was purchased in the form of sheet and tube, from which both bend and tensile specimens were machined. Vari- 
ables studied included pre-age annealing temperature, aging temperature, time, and environment, welding, and hydrogen doping. The effect of these variables on the bend ductility of T-111 are summarized in this section.

Effects of processing history. - One of the purposes of this investigation was to determine if the different processing histories for $\mathrm{T}-111$ sheet and tubing would have an effect on subsequent response to long term aging. Based on the bend test results summarized in table III, there appears to be little difference in the bend ductilities of the two material conditions after undergoing similar aging treatments. The only exception to this general observation is specimens having larger grain sizes as a result of pre-age annealing at $1815^{\circ}$ and $1980^{\circ} \mathrm{C}$, where tube specimens are noted to be more brittle.

Effects of pre-age annealing temperature. - The effect of pre-age annealing temperature on the ductility of $\mathrm{T}-111$ tube that was subsequently aged in lithium for 1000 hours at $1040^{\circ} \mathrm{C}$ is shown in figure 5. Specimens were brittle at $-196^{\circ} \mathrm{C}$ after all pre-age annealing treatments. It can be seen in figure 5 that, as the pre-age annealing temperature is increased to $1980^{\circ} \mathrm{C}, \mathrm{T}-111$ becomes brittle at $25^{\circ} \mathrm{C}$. The loss in ductility is attributed in part to the large 150-micrometer grain size of these specimens as compared with grain sizes of 26 and 52 micrometers for specimens annealed at $1650^{\circ}$ and $1815^{\circ} \mathrm{C}$, respectively. (See fig. 3.)

Effects of aging conditions. - Figure 6 illustrates the effects of aging temperature on the bend ductility of T-111 tube where it is shown that the annealed specimens and those aged at $925^{\circ}$ and $1150^{\circ} \mathrm{C}$ could undergo a full $180^{\circ}$ - ot bend at $-196^{\circ} \mathrm{C}$ without fracture or cracking. In contrast, specimens aged at $1040^{\circ} \mathrm{C}$ fractured with essentially no ductility under similar test conditions. This lack of ductility will be termed aging embrittlement and seems to be confined to specimens aged over a narrow temperature range near $1040^{\circ} \mathrm{C}$. Previous results (refs. 3 to 5 ) have suggested that aging near $1040^{\circ} \mathrm{C}$ can produce some loss in room temperature $\left(25^{\circ} \mathrm{C}\right)$ ductility; however, it was difficult to distinguish between aging-embrittlement caused by hydrogen pick-up during room temperature testing in a moist atmosphere (ref. 5). The current results obtained at $-196^{\circ} \mathrm{C}$ in a liquid nitrogen bath (thus eliminating the possibility of hydrogen pick up during testing) clearly demonstrate that $\mathrm{T}-111$ is embrittled by long-term aging at $1040^{\circ} \mathrm{C}$.

The remaining aging conditions investigated, time and environment, had very little effect on bend ductility of T-111. Extending the aging time to 5000 hours at $1040^{\circ} \mathrm{C}$ resulted in brittle behavior at $-196^{\circ} \mathrm{C}$ and ductile behavior at $25^{\circ} \mathrm{C}$, which is equivalent to the results obtained after the standard 1000-hour treatment. Table III reveals that there was only one instance where aging environment apparently had an effect. Specimens pre-aged annealed at $1815^{\circ} \mathrm{C}$ and then aged in lithium were brittle on testing at $-196^{\circ} \mathrm{C}$, while a specimen aged in vacuum and subsequently tested at $-196^{\circ} \mathrm{C}$, completed the bend test but exhibited some cracking during the flattening test. 
Effects of welding-sheet. - Several of the bend specimens were welded before the standard aging treatment. Table III summarizes the bend test results where, it should be noted, the as-welded specimen was ductile at $-196^{\circ} \mathrm{C}$. Since the standard aging treatment $\left(1000\right.$ hours at $\left.1040^{\circ} \mathrm{C}\right)$ produced brittle behavior in $\mathrm{T}-111$ at $-196^{\circ} \mathrm{C}$, bend tests on welded and aged T-111 were conducted only at $25^{\circ} \mathrm{C}$. All the welded plus aged specimens listed in table III were brittle at $25^{\circ} \mathrm{C}$. A similar loss in ductility has been reported previously for welded T-111 after aging for 1000 to 10000 hours over the temperature range $980^{\circ}$ to $1150^{\circ} \mathrm{C}$ (ref. 3).

Table II lists the oxygen and nitrogen contents of welded T-111 specimens that were aged in lithium. Comparison with nonwelded material indicates no major differences in interstitials as a result of welding and aging in lithium. Photomicrographs of a welded specimen are shown in figure 7 where the weld area and heat affected zone are compared with the base metal. It is concluded that the large grain size in the weld area contributes to the brittle behavior of the welded and aged T-111 specimens at $25^{\circ} \mathrm{C}$. This brittle behavior is similar to the results obtained on specimens pre-aged annealed at $1980^{\circ} \mathrm{C}$, which also produced a large grain size and exhibited brittle failure at $25^{\circ} \mathrm{C}$ after aging.

Effects of hydrogen doping. - The susceptibility of T-111 to hydrogen embrittlement in the annealed and aged conditions is also summarized in table III. Hydrogen analysis for several of the sheet specimens is listed in table II, where it should be noted that the average hydrogen content for all of the T-111 specimens (aged or unaged) is approximately $10 \mathrm{ppm}$. Thus, aging had no significant effect on the bulk hydrogen content.

The bend test results indicate that $\mathrm{T}-111$ tube may be more susceptible than sheet to hydrogen embrittlement in the annealed (unaged) condition. Also, after aging at $925^{\circ} \mathrm{C}$ and then doping with hydrogen, $\mathrm{T}-111$ sheet was ductile at $25^{\circ} \mathrm{C}$, while the comparable tube specimen was brittle. Except for these two instances, sheet and tube exhibited similar susceptibilities to hydrogen embrittlement. Figure 8 summarizes the bend test results for $\mathrm{T}-111$ sheet doped with hydrogen. It should be noted that sheet aged at $925^{\circ} \mathrm{C}$ and then doped with $10 \mathrm{ppm}$ hydrogen, still exhibited some ductility at $-196^{\circ} \mathrm{C}$. In contrast, $\mathrm{T}-111$ sheet aged at $1040^{\circ}$ or $1150^{\circ} \mathrm{C}$ and then doped with $10 \mathrm{ppm}$ hydrogen was brittle at the less severe test temperature of $25^{\circ} \mathrm{C}$.

These results on T-111 sheet support the previous results reported by Watson and Stephens (ref. 5) that aging T-111 near $1040^{\circ} \mathrm{C}$ increases its susceptibility to hydrogen embrittlement. In addition, the results show that the ductile-brittle transition temperature can be increased in excess of $200^{\circ} \mathrm{C}$ for $\mathrm{T}-111$ tubing aged at $925^{\circ}$ and $1150^{\circ} \mathrm{C}$ as a result of doping with about $10 \mathrm{ppm}$ hydrogen. However, this embrittlement is not related solely to the bulk hydrogen content since all of the hydrogen doped specimens had about the same bulk hydrogen content but exhibited varying degrees of embrittlement. 


\section{Bend Ductility of Other Tantalum Alloys}

As indicated in the flow chart shown in figure $1(\mathrm{~b})$, the seven modified composition Ta alloys were purchased only in the form of sheet, and were given only the standard annealing $\left(1 \mathrm{hr}\right.$ at $1650^{\circ} \mathrm{C}$ and $1 \mathrm{hr}$ at $\left.1315^{\circ} \mathrm{C}\right)$ and aging $\left(1000 \mathrm{hr}\right.$ at $1040^{\circ} \mathrm{C}$ in lithium and vacuum) treatments. Several of the bend specimens underwent a simulated buttweld before aging and several bend specimens were hydrogen doped in the annealed and aged conditions. The effects of these variables on the bend ductility of the sheet specimens are summarized in this section. Results of similar tests on T-111 are included in this section for comparison.

Effects of composition on aging embrittlement. - The effect of alloy composition on the susceptibility of Ta alloys to aging embrittlement is summarized in table IV for the eight Ta alloys. The bend ductility is given for specimens in the annealed condition and after the standard aging treatment of 1000 hours at $1040^{\circ} \mathrm{C}$ in lithium or vacuum. All specimens were ductile upon testing at $-196^{\circ} \mathrm{C}$ in the pre-age annealed condition. Only two of the alloys, Ta-8W-2Hf (T-111) and Ta-8W-3Hf, are susceptible to aging embrittlement as measured by bend ductility at $-196^{\circ} \mathrm{C}$. These two alloys contain the greatest amounts of combined $W$ and Hf. This suggests that the combined levels of $W$ and Hf have an important affect on the alloy's susceptibility to hydrogen embrittlement.

The effects of aging for 1000 hours at $1040^{\circ} \mathrm{C}$ on welded specimens from each of the alloys (except for ASTAR-811C) are similar to those for the unwelded sheet: aging embrittlement occurred only in the Ta-8W-2H (T-111) and Ta-8W-3Hf alloys. The degree of embrittlement for these two alloys was more severe for the welded specimens since they also exhibited brittle behavior at $25^{\circ} \mathrm{C}$, while the unwelded aged specimens were ductile at this temperature.

Effects of composition on hydrogen embrittlement. - Bend data for the hydrogen doped Ta alloys also are summarized in table IV. The bend ductility is shown in figures 8 and 9 . In the annealed (unaged) condition, only Ta-8W-2Hf (T-111) indicated any evidence of loss in ductility during bend testing at $-196^{\circ} \mathrm{C}$ due to the addition of approximately $8 \mathrm{ppm}$ hydrogen. Aging and then doping with hydrogen resulted in embrittlement of all the alloys except for the two binary alloys (Ta-10W and Ta-2Hf). The binary alloy Ta-10W exhibited only slight surface cracks after completing a $180^{\circ}$ bend at $-196^{\circ} \mathrm{C}$, and the binary alloy Ta-2Hf showed no loss of ductility at $-196^{\circ} \mathrm{C}$ as a result of the hydrogen addition.

Hydrogen embrittlement was most severe in the Ta-8W-2Hf (T-111) and Ta-8W-3Hf alloys, the specimens being brittle at $25^{\circ} \mathrm{C}$ after aging in either lithium or vacuum. In contrast, the ductility at $25^{\circ} \mathrm{C}$ of the remaining ternary alloys and ASTAR-811C showed a dependence on aging environment. Specimens of these alloys aged in lithium fractured in a brittle manner at essentially zero bend angle, while specimens aged in vacuum 
could withstand a $180^{\circ}$ bend with only surface cracks appearing. This apparent dependence on aging environment can be explained by an examination of the hydrogen contents of the doped alloy specimens (see table II). Specimens that were aged in lithium picked up approximately 25 to $30 \mathrm{ppm}$ hydrogen during doping while those that had been aged in vacuum picked up approximately 10 to $15 \mathrm{ppm}$ hydrogen during doping at the same time under identical conditions. The reason for this difference in behavior might be associated with the lowering of the oxygen content (table II) of the Ta alloys during lithium aging while aging in vacuum had little effect on oxygen content. Subsequent doping in hydrogen might then permit the higher purity, lithium-aged specimens to pick up more hydrogen than the vacuum-aged specimens. Therefore, the specimens with the higher hydrogen contents had less ductility than those specimens with a lower hydrogen content, as would be anticipated. The T-111 specimens, did not exhibit this dependence on aging environment, probably because of the nitrogen contamination.

\section{Tensile Properties of Ta Alloys}

Tensile tests were conducted on all of the Ta alloys (except for ASTAR-811C) over the temperature range $25^{\circ}$ to $1180^{\circ} \mathrm{C}$. In general, the tensile behavior of all the Ta alloys was similar and was characterized by three distinct types of stress-strain curves depending on the test temperature. Generalized stress-strain curves, which represent the three types of tensile behavior, are shown in figure 10. At lower test temperatures (from $25^{\circ}$ to $620^{\circ} \mathrm{C}$ ), the alloys exhibited a yield point drop that is attributed to locking of dislocations by interstitial impurities present in the alloys. At the highest test temperatures $\left(1040^{\circ}\right.$ to $\left.1180^{\circ} \mathrm{C}\right)$, smooth stress-strain curves were observed. And at the intermediate test temperatures (primarily from $760^{\circ}$ to $1040^{\circ} \mathrm{C}$ ), serrated flow curves characterized the alloys. This behavior is attributed to dynamic strain-aging, which is due to repeated breaking away of dislocations from impurity atmospheres and subsequent locking of dislocations by impurity atmospheres. Dynamic strain-aging has been observed previously in T-111 by Sheffler, Sawyer, and Steigerwald (ref. 8). Based on a comparison of the activation energy for strain aging and the activation energy for diffusion of each of the interstitial impurities in T-111, Sheffler, Sawyer, and Steigerwald concluded that oxygen is the critical interstitial specie responsible for dynamic strain aging in T-111. The dynamic strain aging observed in the seven Ta-base alloys tested in the present study is assumed to be due to a similar interaction. However, nitrogen may have contributed to dynamic strain-aging in the T-111 alloy specimens aged in lithium.

Tensile strength of T-111. - The results of tensile testing T-111 sheet and tube in the annealed and aged conditions are summarized in table V. Based on a comparison of the data for sheet and tube $\mathrm{T}-111$, it is concluded that processing history does not have a 
significant effect on tensile properties of $\mathrm{T}-111$ over the temperature range used in this study. Figures 11 to 13 show the effects of aging temperature, pre-age annealing temperature, and aging time on the ultimate tensile stress (UTS) and lower yield stress (LYS) or 0.2 percent offset stress of T-111 sheet. In general, the various aging treatments had a minor effect on the yield stress of T-111, as shown in these figures. And no significant effects on tensile elongation values were apparent (see table V). The main effect of aging on the alloy strength was to lower the ultimate tensile stress over the temperature range of about $600^{\circ}$ to $1040^{\circ} \mathrm{C}$. The strengthening due to dynamic strain aging in the annealed material over this temperature range was minimized as a result of long-time aging. Specimens aged in lithium at $925^{\circ} \mathrm{C}$ were substantially stronger than the other annealed and aged specimens (fig. 11(b)). This higher strength may be due to the segregation of nitrogen to dislocations at this aging temperature, which in turn may contribute to the UTS of these specimens.

Tensile strength of other Ta alloys. - Tensile properties of the six other Ta alloys are summarized in table VI. Again, the tensile elongation values appear to be unaffected by the aging conditions. The effects of aging for 1000 hours at $1040^{\circ} \mathrm{C}$ on the tensile strength of each of these alloys are shown in figure 14. The most marked effect of aging occurred in the binary alloys Ta-10W and Ta-2Hf. Figure 14(a) shows that both the ultimate tensile stress and yield stress of Ta-10W decreased substantially as a result of aging, with a lithium environment having a greater effect than vacuum. Aging of Ta-2Hf (fig. 14(f)) minimized the effects of dynamic strain-age strengthening over the $600^{\circ}$ to $1040^{\circ} \mathrm{C}$ temperature range for the ultimate tensile stress and decreased the yield stress primarily over the $25^{\circ}$ to $500^{\circ} \mathrm{C}$ temperature range. In contrast, the ternary alloys (other than T-111) exhibited only minor variations of ultimate tensile stress and yield stress with aging in either lithium or vacuum. Examination of table II indicates that the greatest reduction in oxygen content as a result of aging in vacuum and especially in lithium occurred for the two binary alloys, Ta-10W and Ta-2Hf. This loss of oxygen may account for the reduction in strength of these alloys as a result of aging.

A comparison of the ultimate tensile stress of the seven Ta alloys is shown in figure 15 for both the annealed and aged conditions. At the aging temperature and potential use temperature of $1040^{\circ} \mathrm{C}$, it should be noted that $\mathrm{T}-111$ has the highest ultimate tensile stress of the seven Ta alloys. (Similar results were observed in comparing the yield stress of these alloys.)

\section{Scanning Electron Microscopy Examination}

The effect of alloy composition on the aging embrittlement of these Ta-base alloys suggests that there is a critical combination of $\mathrm{W}$ and Hf required to produce the em- 
brittlement phenomenon in Ta-base alloys. Bend tests at $-196^{\circ} \mathrm{C}$ showed that aging embrittlement occurred only in the alloys with high combined levels of $\mathrm{W}$ and Hf, that is $\mathrm{T}-111$ (Ta-8W-2Hf) and the Ta-8W-3Hf alloy. Reduced levels of either $\mathrm{W}$ or $\mathrm{Hf}$ in these alloys circumvented aging embrittlement. In addition, subsequent hydrogen doping of the aged alloys indicated that the two binary alloys, Ta-10W and Ta-2Hf, were not susceptible to hydrogen embrittlement in the aged condition at hydrogen concentrations ranging from 10 to $25 \mathrm{ppm}$. In contrast, the five ternary alloys and ASTAR-811C were susceptible to hydrogen embrittlement in the aged condition at similar hydrogen concentrations.

Although it is recognized that hydrogen in solution (ref. 10) or as a hydride (ref. 11) can produce embrittlement of Ta alloys, the increased sensitivity to hydrogen embrittlement as a direct result of long-term aging near $1040^{\circ} \mathrm{C}$ is of major concern in the use of Ta alloys such as T-111. The aging embrittlement of only Ta-8W-2Hf and Ta-8W$3 \mathrm{Hf}$ and the hydrogen embrittlement of all but the binary alloys are both believed to be related to the degree of Hf segregation at grain boundaries.

Figure 16 shows scanning electron micrographs of fractured surfaces of the eight Ta alloys that had been aged for 1000 hours at $1040^{\circ} \mathrm{C}$, hydrogen doped and then tested at $25^{\circ} \mathrm{C}$. It should be noted that Ta-10W (fig. 16(a)) failed in a ductile manner (fracture achieved by repeated bending in opposite directions) and was free of precipitate particles at grain boundaries. With increasing $\mathrm{Hf}$ content in the Ta- $8 \mathrm{~W}$ base alloys brittle, intergranular fracture predominates the microstructure with some evidence of ductile tearing as shown in figures 16(b) to (d) for Ta-8W-0.5Hf, Ta-8W-1Re-0.7Hf-0.025C (ASTAR-811C), and Ta-8W-1Hf. But alloys with larger Hf additions fractured in a completely brittle manner as shown in figures $16(\mathrm{e})$ and (f) for Ta-8W-2Hf and Ta-8W3Hf. Brittle, intergranular failure also characterized the Ta-4W-2Hf alloy (fig. 16(g)). However, on complete removal of $\mathrm{W}$ from the alloy system, ductile failure characterized the Ta-2Hf alloy (fig. 16(h)), and the grain boundaries were free of precipitate particles, quite similar to the Ta-10W binary alloy.

Precipitate particles are observed in all the ternary alloys and in ASTAR-811C, which either exhibited predominately or totally brittle, intergranular failure. The Ta-8W-2Hf and Ta-8W-3Hf alloys contained the greatest concentration of precipitate particles at the grain boundaries. These particles were identified previously to be $\mathrm{Hf}$ rich (ref. 5). As either Hf content is reduced to concentrations ranging from 0.5 to 1 percent or $\mathrm{W}$ is reduced to a concentration of 4 percent, fewer particles were observed at the grain boundaries. It is this variation in amount of precipitates at the grain boundaries that is believed to account for the aging embrittlement exhibited only by Ta-8W-2Hf and Ta-8W-3Hf alloys. The remaining ternary alloys and ASTAR-811C with fewer precipitates at the boundaries and the two binary alloys with an absence of precipitate particles did not exhibit aging embrittlement. Upon doping with hydrogen, all the 
alloys containing Hf rich particles at the grain boundaries exhibited hydrogen embrittlement.

\section{DISCUSSION}

\section{Ductility Effects}

The role of Hf in the embrittlement problem of Ta-base alloys is to segregate to grain boundaries during aging. This grain boundary segregation in itself can cause a loss of ductility at $-196^{\circ} \mathrm{C}$, (i.e., aging embrittlement, ref. 12). Subsequent doping with hydrogen contributes an additional embrittling effect, which is evident by the brittle behavior at $25^{\circ} \mathrm{C}$ of aged and hydrogen-doped specimens. It appears that Hf segregation at the grain boundaries compounds the embrittlement caused by hydrogen since no hydrogen embrittlement was observed in Ta-2Hf alloy, where Hf segregation did not occur. This increased embrittlement may arise because the Hf segregated at grain boundaries may act as a sink for hydrogen segregation at grain boundaries as well, in the ternary and more complex alloys, because of the high affinity for hydrogen by Hf. Alternatively, and less probably, hydrogen may be in solution and may simply be an additive effect to the aging embrittlement caused by Hf segregation.

One of the more interesting observations of the compositional dependence of aging embrittlement was the absence of Hf segregation in the binary Ta-2Hf alloy. This suggests that the presence of $\mathrm{W}$ in the ternary alloys affects the rate and degree of grain boundary Hf segregation. A possible explanation is that the lattice contraction that occurs upon adding $\mathrm{W}$ to $\mathrm{Ta}$ (ref. 13) causes the larger Hf atoms to segregate to misfit or grain boundary areas. Competing with this equilibrium segregation process is diffusion, which will tend to evenly distribute the solute at higher aging temperatures (ref. 14). As was shown in reference 5, T-111 aged for 1000 hours at $1315^{\circ} \mathrm{C}$ did not exhibit precipitate particles at grain boundaries, did not exhibit aging embrittlement, and was not susceptible to hydrogen embrittlement. Aging at lower temperatures would favor segregation of $\mathrm{Hf}$ to misfit areas; however, longer aging times would be required for the Hf to diffuse to the misfit or grain boundary areas. Hence, T-111 specimens aged at $925^{\circ}$ for 1000 hours and then hydrogen doped, still exhibited some ductility at $-196^{\circ} \mathrm{C}$ (as was shown in fig. 8). Longer aging times at this temperature would probably cause complete embrittlement.

The scanning electron micrographs of figure 17 illustrate the effect of aging temperature on the fracture behavior and confirm the proposed variation of Hf segregation with aging temperature. For specimens aged 1000 hours and then hydrogen doped, it is noted from figure 17(a) that a predominately ductile fracture occurred with no evidence 
of precipitate particles at grain boundaries for $\mathrm{T}-111$ aged at $925^{\circ} \mathrm{C}$. In figure $17(\mathrm{~b})$ $\mathrm{T}-111$ aged at $1040^{\circ} \mathrm{C}$ failed in a brittle, intergranular manner with a high density of Hf-rich precipitate particles at the grain boundaries. In figure 17(c) T-111 aged at $1150^{\circ} \mathrm{C}$ failed primarily by intergranular fracture; however, the amount of Hf-rich precipitate is less than for material aged at $1040^{\circ} \mathrm{C}$. These scanning micrographs support the ideas that there are competing processes for $\mathrm{Hf}$ segregation and homogenization and that $1040^{\circ} \mathrm{C}$ appears to be near the critical temperature where Hf segregation occurs to the greatest extent after long-term aging.

\section{Strength Effects}

The results of this study indicate that the primary effect of long-term aging on the elevated temperature tensile strength of the Ta-base alloys tested in this program was to reduce the strengthening contributed by dynamic strain-aging. This apparently is due to the removal of oxygen during aging, which is the interstitial specie responsible for dynamic strain-aging. Although the effect was relatively minor for short tensile tests, Sheffler and Buzzard (ref. 15) have shown that aging at $1040^{\circ} \mathrm{C}$ can produce a major reduction in the creep life of $\mathrm{T}-111$ apparently because of removal of oxygen during aging.

For applications of Ta alloys at temperatures near $1040^{\circ} \mathrm{C}$, it appears from the results of this study that an alloy having either lower Hf or lower W contents than the concentrations in T-111 would be desirable. It is interesting to compare the strength of T-111 with Ta-8W-1Hf, an alloy that does not exhibit aging embrittlement but still has Hf present to prevent corrosion in a liquid metal environment. The tensile strength at $1040^{\circ} \mathrm{C}$ of annealed Ta-8W-1Hf is 64 percent of that for $\mathrm{T}-111$ and increases to 73 percent after aging in vacuum while the yield strength is 72 percent for the annealed condition and 75 percent after vacuum aging. Therefore, substituting Ta-8W-1Hf for $\mathrm{T}-111$ to avoid aging embrittlement, results in an approximate 25 percent reduction in strenght. A stronger alloy may be the more complex Ta-base alloy ASTAR-811C. (Ta-8W-1Re-0.7Hf-0.025C), which also did not exhibit aging embrittlement and has short-time tensile strength properties at $1040^{\circ} \mathrm{C}$ slightly superior to $\mathrm{T}-111$ (ref. 9).

\section{Applicability of Results to Alloy Selection}

The selection of ductile Ta-base alloys for liquid metal service will have to take into consideration the operating temperature and strength requirements of the specific 
application. For operating temperatures near $1040^{\circ} \mathrm{C}, \mathrm{T}-111$ should not be used because of potential embrittlement. Alternative alloys for this use could be low-strength binary alloys (such as Ta-2Hf), intermediate-strength alloys that are modified forms of T-111 (such as Ta-8W-0.5Hf, Ta-8W-1Hf, or Ta-4W-2Hf), or more-complex high strength alloys (such as ASTAR-811C). For higher operating temperatures (e.g., above $\left.1300^{\circ} \mathrm{C}\right), \mathrm{T}-111$ is still an attractive candidate because it is well-characterized and it does not suffer from embrittlement at these higher temperatures.

In all cases involving ternary (or more complex) Ta-base alloys, great care must be exercised to prevent the exposure of the material to hydrogen. All of these materials are susceptible to hydrogen embrittlement, and this susceptability increases after long-term aging.

\section{CONCLUSIONS}

Based on a study of the effects of alloy composition and aging conditions on the aging embrittlement, susceptibility to hydrogen embrittlement, and the tensile properties of tantalum-tungsten-hafnium alloys, the following conclusions are drawn:

1. Aging embrittlement is a different phenomenon than hydrogen embrittlement. Aging embrittlement, which is characterized by brittle, intergranular failure, is due to the segregation of hafnium to the grain boundaries. This segregation is dependent on the tungsten concentration in the alloy and on the aging temperature of the alloy. Hafnium segregation is greatest in alloys aged for long times near $1040^{\circ} \mathrm{C}$.

2. A critical combination of tungsten and hafnium promotes the aging embrittlement of tantalum alloys; this critical combination corresponds to the 8 percent tungsten and 2 percent hafnium in T-111. Reducing either the tungsten or the hafnium contents of this alloy by at least 50 percent can circumvent the aging embrittlement problem.

3. Hafnium grain boundary segregation also increases the sensitivity of the Ta alloys to hydrogen embrittlement, possibly by acting as a grain boundary sink for hydrogen segregation.

4. In general, the material processing history (sheet, tube, or weldments) has only a minor effect on the bend ductility of T-111 after various annealing, aging and hydrogen doping treatments. Tube material and weldments were slightly more susceptible than sheet to grain size effects and hydrogen doping.

5. Modifying the $\mathbf{T}-111$ composition by reducing either the tungsten or hafnium content will result in a reduction of the ultimate tensile stress and yield stress of $\mathrm{T}-111$. Reducing the tungsten or hafnium content by 50 percent will result in a 25 - to 40 -percent reduction in both ultimate and yield stress at $1040^{\circ} \mathrm{C}$. 
For use with alkali metals at $1040^{\circ} \mathrm{C}$ where a strength equivalent to $\mathrm{T}-111$ is required, use of an alloy such as ASTAR-811C is attractive. Since the aging embrittlement occurring in T-111 results because of aging near $1040^{\circ} \mathrm{C}, \mathrm{T}-111$ is still an attractive alloy for use at higher temperatures, near $1300^{\circ} \mathrm{C}$ for example.

Lewis Research Center,

National Aeronautics and Space Administration,

Cleveland, Ohio, August 16, 1974,

501-21.

\section{REFERENCES}

1. Moss, T. A.; Davies, R. L.; and Barna, G. J. : Refractory-Alloy Requirements for Space Power Systems. Recent Advances in Refractory Alloys for Space Power Systems. NASA SP-245, 1970, pp. 1-18.

2. Ekvall, R. A.; Frank, R. G.; and Young, W. R.: T-111 Alloy Cracking Problems During Processing and Fabrication. Recent Advances in Refractory Alloys for Space Power Systems. NASA SP-245, 1970, pp. 221-260.

3. Lessman, G. G.; and Gold, R. E. : Determination of the Weldability and Elevated Temperature Stability of Refractory Metal Alloys. II - Long-Time Temperature Stability of Refractory Metal Alloys. NASA CR-1608, 1970.

4. Harrison, R. W. ; and Smith, J. P.: Advanced Refractory Alloy Corrosion Loop Program. GESP-562, General Electric Co. (NASA CR-72818), 1970.

5. Watson, Gordon K. ; and Stephens, Joseph R. : Effect of Aging at $1040^{\circ} \mathrm{C}\left(1900^{\circ} \mathrm{F}\right)$ on the Ductility and Structure of a Tantalum Alloy, T-111. NASA TN D-6988, 1972.

6. Gahn, Randall F. : Techniques for Lithium Removal from $1040^{\circ} \mathrm{C}$ Aged Tantalum Alloy, T-111. NASA TM X-2775, 1973.

7. Buzzard, Robert J.; and Metroka, Robert R. : Effect of Nitrogen on Tensile Properties and Structures of T-111 (Tantalum-8-Percent-Tungsten-2-Percent-Hafnium) Tubing. NASA TN D-6999, March, 1973.

8. Sheffler, K. D.; Sawyer, J. C.; and Steigerwald, E. A. : Creep Behavior of Refractory Alloys in Ultrahigh Vacuum. Recent Advances in Refractory Alloys for Space Power Systems. NASA SP-245, 1970, pp. 75-125.

9. Buckman, R. W., Jr.; and Goodspeed, R. C. : Precipitation Strengthened Tantalum Base Alloys. NASA CR-1642, 1971. 
10. Chandler, W. T.; and Walter, R. J.: Hydrogen Effects in Refractory Metals. Symposium on Metallurgy and Technology of Refractory Metal Alloys. I. Machlin, R. T. Begley, and E. D. Weisert, eds., Plenum Press, 1968, pp. 197-250.

11. Stephens, Joseph R.; and Garlick, Ralph G. : Compatibility of Tantalum, Columbium, and Their Alloys with Hydrogen in Presence of Temperature Gradient. NASA TN D-3546, 1966.

12. Stephens, J. R.: Role of Hf and $\mathrm{Zr}$ in the Hydrogen Embrittlement of Ta and Cb Alloys. NASA TM X-68293, 1973.

13. Pearson, William B. : A Handbook of Lattice Spacings and Structures of Metals and Alloys. Hydrogen In Metals, American Society For Metals, 1974, pp. 383-392.

14. McLean, D. : Grain Boundaries in Metals. Clarendon Press, 1957.

15. Sheffler, K. D.; and Buzzard, R. J.: Effect of Long-Time, Elevated-Temperature Exposures to Vacuum and Lithium on the Properties of a Tantalum Alloy T-111. NASA TN D-7548, 1974. 


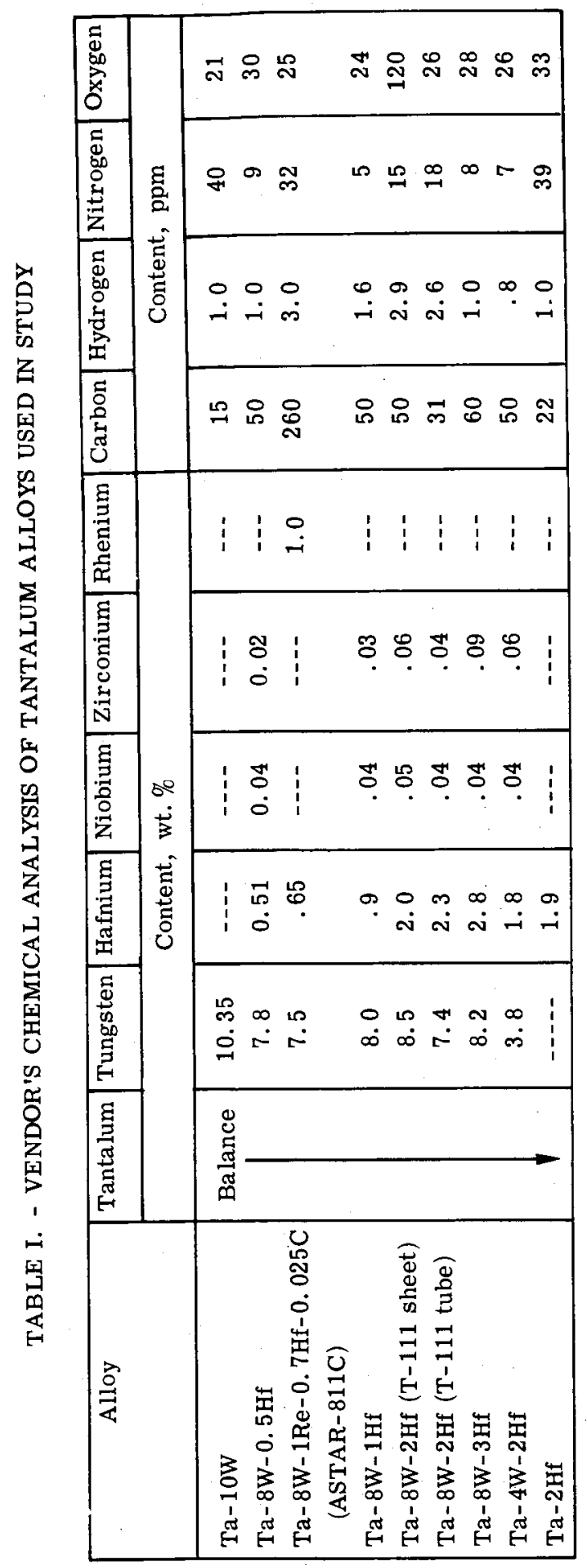




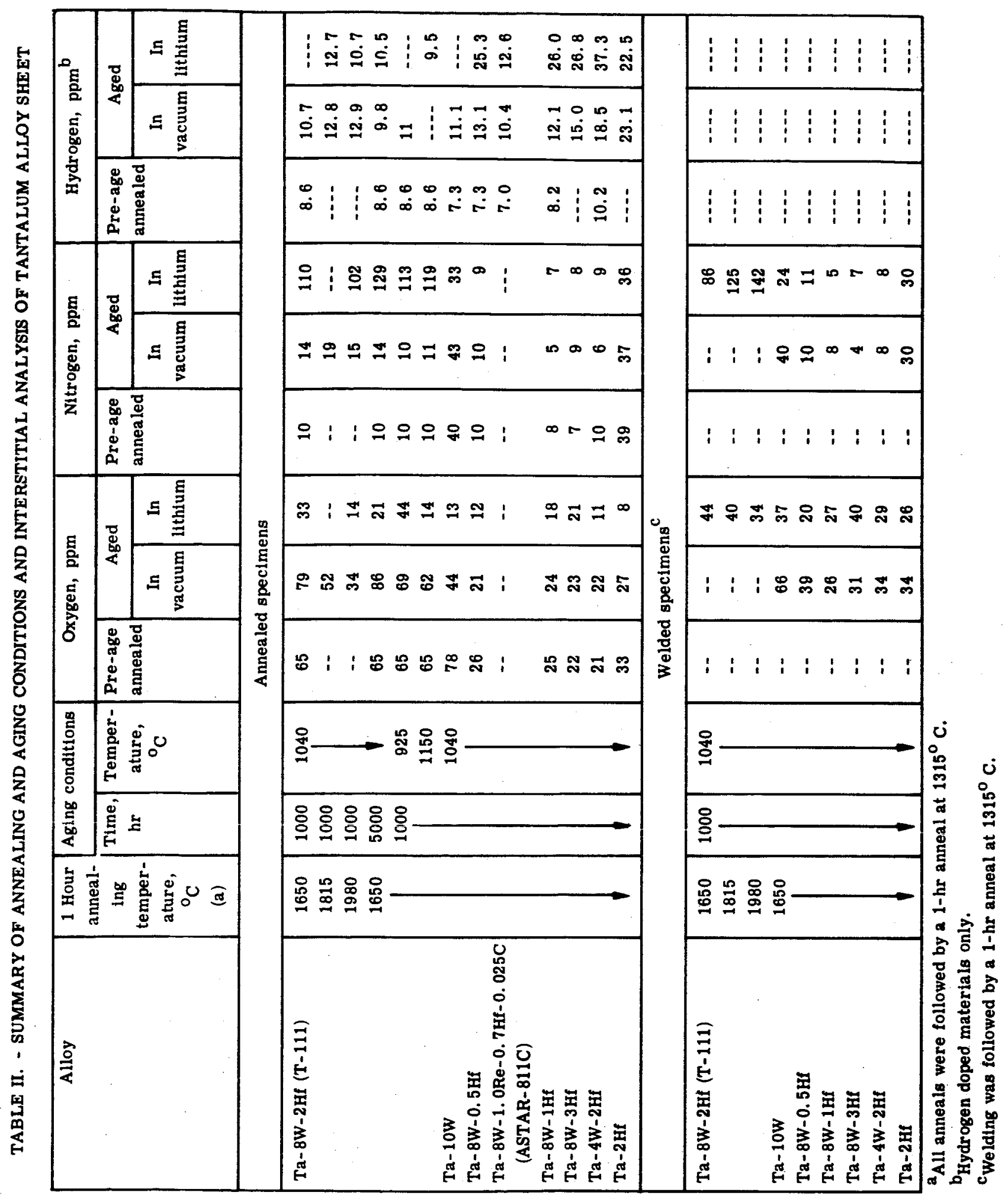


TABLE III. - EFFECT OF AGING CONDITIONS AND HYDROGEN DOPING ON BEND DUCTILITY OF T-111 SHEET AND TUBING

\begin{tabular}{|c|c|c|c|c|c|c|c|}
\hline \multirow{3}{*}{$\begin{array}{c}\text { Annealing } \\
\text { temper - } \\
\text { ature, } \\
{ }^{\circ} \mathrm{C}\end{array}$} & \multicolumn{3}{|c|}{ Aging conditions } & \multirow{3}{*}{$\begin{array}{c}\text { Hydrogen } \\
\text { doped }\end{array}$} & \multicolumn{3}{|c|}{ Bend tests } \\
\hline & \multirow{2}{*}{$\begin{array}{c}\text { Time, } \\
\mathrm{hr}\end{array}$} & \multirow{2}{*}{$\begin{array}{c}\text { Temper- } \\
\text { ature, } \\
{ }^{0} \mathrm{C}\end{array}$} & \multirow[t]{2}{*}{ Environment } & & \multirow{2}{*}{$\begin{array}{c}\text { Temper- } \\
\text { ature, } \\
{ }^{\circ} \mathrm{C}\end{array}$} & \multicolumn{2}{|c|}{ Results } \\
\hline & & & & & & Sheet & Tube \\
\hline \multicolumn{8}{|c|}{ Effect of annealing } \\
\hline 1650 & --- & --- & ------ & No & -196 & Ductile & Ductile \\
\hline 1650 & $-\cdots$ & --- & ------ & $\begin{array}{l}\text { Yes } \\
\text { Yes }\end{array}$ & $\begin{array}{r}-196 \\
25 \\
\end{array}$ & Cracks & $\begin{array}{l}\text { Brittle } \\
\text { Ductile }\end{array}$ \\
\hline \multicolumn{8}{|c|}{ Effect of pre-age annealing temperature } \\
\hline 1815 & 1000 & $\begin{array}{c}1040 \\
\mid\end{array}$ & $\begin{array}{l}\text { Lithium } \\
\text { Lithium } \\
\text { Vacuum } \\
\text { Vacuum } \\
\text { Lithium } \\
\text { Lithium } \\
\text { Vacuum } \\
\text { Vacuum } \\
\text { Lithium } \\
\text { Lithium } \\
\text { Vacuum } \\
\text { Vacuum }\end{array}$ & $\begin{array}{c}\text { No } \\
\mid\end{array}$ & $\begin{array}{r}-196 \\
25 \\
-196 \\
25 \\
-196 \\
25 \\
-196 \\
25 \\
-196 \\
25 \\
-196 \\
25 \\
\end{array}$ & $\begin{array}{l}\text { Ductile } \\
\text { Brittle } \\
\text { Ductile } \\
\text { Brittle } \\
\text { Ductile } \\
\text { Ductile } \\
\text { Ductile } \\
\text { Brittle } \\
\text { Ductile }\end{array}$ & $\begin{array}{l}\text { Brittle } \\
\text { Ductile } \\
\text { Brittle } \\
\text { Ductile } \\
\text { Brittle } \\
\text { Ductile } \\
\text { Cracks } \\
\text { Ductile } \\
\text { Brittle } \\
\end{array}$ \\
\hline $\begin{array}{l}1650 \\
1815 \\
1980\end{array}$ & $\begin{array}{c}1000 \\
1\end{array}$ & $\begin{array}{c}1040 \\
\mid\end{array}$ & $\begin{array}{l}\text { Lithium } \\
\text { Lithium } \\
\text { Vacuum } \\
\text { Vacuum } \\
\text { Lithium } \\
\text { Lithium }\end{array}$ & $\begin{array}{c}\text { Yes } \\
\mid\end{array}$ & $\begin{array}{r}-196 \\
25 \\
-196 \\
25 \\
-196 \\
25 \\
\end{array}$ & Brittle & $\begin{array}{l}\text { Brittle } \\
\text { Brittle } \\
\text { Brittle }\end{array}$ \\
\hline \multicolumn{8}{|c|}{ Effect of aging time } \\
\hline 1650 & 1 & 1040 & $\begin{array}{l}\text { Lithium } \\
\text { Lithium } \\
\text { Vacuum } \\
\text { Vacuum }\end{array}$ & $\begin{array}{c}\text { No } \\
\mid\end{array}$ & $\begin{array}{r}-196 \\
25 \\
-196 \\
25 \\
\end{array}$ & $\begin{array}{l}\text { Brittle } \\
\text { Ductile } \\
- \\
\text { Ductile }\end{array}$ & $\begin{array}{l}\text { Brittle } \\
\text { Ductile } \\
\text { Brittle } \\
\text { Ductile }\end{array}$ \\
\hline 1650 & $\begin{array}{l}5000 \\
5000 \\
5000\end{array}$ & $\begin{array}{l}1040 \\
1040 \\
1040\end{array}$ & $\begin{array}{l}\text { Lithium } \\
\text { Vacuum } \\
\text { Vacuum }\end{array}$ & $\begin{array}{l}\text { Yes } \\
\text { Yes } \\
\text { Yes }\end{array}$ & $\begin{array}{r}25 \\
-196 \\
25\end{array}$ & Brittle & Brittle \\
\hline \multicolumn{8}{|c|}{ Effect of aging temperature } \\
\hline 1650 & $\stackrel{1}{1000}$ & $\begin{array}{r}925 \\
925 \\
1150 \\
1150 \\
\end{array}$ & $\begin{array}{l}\text { Lithium } \\
\text { Vacuum } \\
\text { Lithium } \\
\text { Vacuum }\end{array}$ & No & -196 & Ductile & Ductile \\
\hline 1650 & 1000 & $\begin{array}{r}925 \\
925 \\
1150 \\
1150 \\
\end{array}$ & $\begin{array}{l}\text { Vacuum } \\
\text { Vacuum } \\
\text { Lithium } \\
\text { Lithium }\end{array}$ & $\begin{array}{c}\text { Yes } \\
\end{array}$ & $\begin{array}{r}-196 \\
25 \\
-196 \\
25 \\
\end{array}$ & $\begin{array}{l}90^{\circ} \text { Bend } \\
\text { Ductile } \\
\text { Brittle } \\
\text { Brittle }\end{array}$ & Brittle \\
\hline \multicolumn{8}{|c|}{ Effect of welding } \\
\hline 1815 & $\begin{array}{c}1000 \\
1\end{array}$ & $\begin{array}{c}1040 \\
1\end{array}$ & $\begin{array}{l}\text { Lithium } \\
\text { Vacuum } \\
\text { Lithium } \\
\text { Vacuum } \\
\text { Lithium } \\
\text { Vacuum }\end{array}$ & $\begin{array}{r}\text { No } \\
1\end{array}$ & $\begin{array}{r}-196 \\
25 \\
\mid\end{array}$ & $\begin{array}{l}\text { Ductile } \\
\text { Brittle }\end{array}$ & - \\
\hline
\end{tabular}




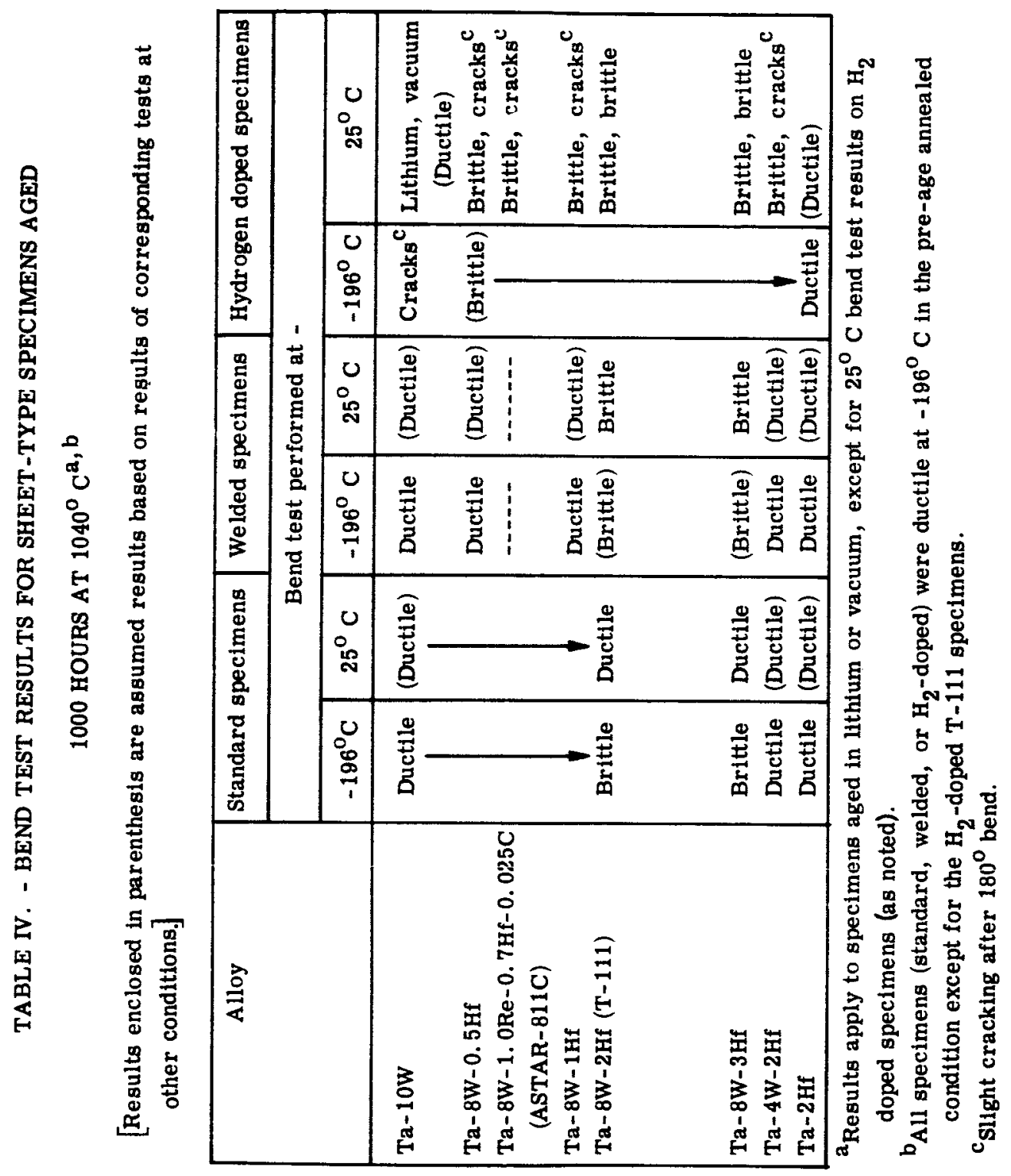


TABLE V. - SUMMARY OF TENSILE DATA FOR T-111

(a) T-111 sheet

\begin{tabular}{|c|c|c|c|c|c|c|c|c|c|}
\hline \multirow{3}{*}{$\begin{array}{l}\text { Annealing } \\
\text { temper- } \\
\text { ature, } \\
{ }^{\circ} \mathrm{C}\end{array}$} & \multicolumn{3}{|c|}{ Aging conditions } & \multirow{3}{*}{$\begin{array}{l}\text { Test tem- } \\
\text { perature, } \\
{ }^{\mathrm{o}} \mathrm{C}\end{array}$} & \multirow{2}{*}{\multicolumn{2}{|c|}{$\begin{array}{l}\text { Ultimate tensile stress, } \\
\qquad \sigma_{\text {UTS' }} \\
\text { MN } / \mathrm{m}^{2}\end{array}$}} & \multirow{2}{*}{\multicolumn{2}{|c|}{$\begin{array}{c}\text { Yield stress, } \\
{ }^{\sigma} \mathrm{YS} \\
\mathrm{MN} / \mathrm{m}^{2}\end{array}$}} & \multirow{3}{*}{$\begin{array}{c}\text { Elongatic: } \\
\text { percent }\end{array}$} \\
\hline & \multirow[t]{2}{*}{$\begin{array}{c}\text { Time, } \\
\text { hr }\end{array}$} & \multirow{2}{*}{$\begin{array}{l}\text { Temper- } \\
\text { ature, } \\
{ }^{\circ} \mathrm{C}\end{array}$} & \multirow[t]{2}{*}{ Environment } & & & & & & \\
\hline & & & & & Maximum & Minimum & Upper & Lower ${ }^{\mathrm{a}}$ & \\
\hline \multirow[t]{7}{*}{1650} & --- & $\ldots-$ & ----- & 25 & 630 & -- & 569 & 541 & 37 \\
\hline & $-\ldots$ & --- & $----n$ & 480 & 475 & -- & 451 & 380 & 27 \\
\hline & ---- & --- & $---\infty--$ & 620 & 465 & 453 & 352 & 310 & 19 \\
\hline & --- & --- & ----- & 760 & 499 & -- & 325 & 308 & 23 \\
\hline & --- & $-\ldots$ & ---- & 900 & 461 & 423 & 251 & 250 & 23 \\
\hline & $\ldots$ & ---- & $----n$ & 1040 & 444 & 400 & 230 & 230 & 23 \\
\hline & --- &.-- & ----- & 1180 & 345 & --- & --- & 209 & 35 \\
\hline \multirow[t]{6}{*}{1650} & \multirow[t]{6}{*}{1000} & \multirow[t]{6}{*}{925} & \multirow[t]{3}{*}{ Lithium } & 25 & 750 & -- & $\cdots$ & 632 & 30 \\
\hline & & & & 480 & 598 & --- & $\ldots$ & 496 & 29 \\
\hline & & & & 1040 & 489 & --- & $\cdots$ & 276 & 17 \\
\hline & & & \multirow[t]{3}{*}{ Vacuum } & 25 & 632 & -- & 586 & 550 & 38 \\
\hline & & & & 760 & 447 & --- & 319 & 302 & 23 \\
\hline & & & & 1040 & 418 & 387 & 226 & 226 & 28 \\
\hline \multirow[t]{6}{*}{1650} & \multirow[t]{6}{*}{1000} & \multirow[t]{6}{*}{1150} & \multirow[t]{3}{*}{ Lithium } & 480 & 498 & --- & 426 & 396 & 30 \\
\hline & & & & 760 & 415 & -- & 308 & 297 & 26 \\
\hline & & & & 1040 & 409 & 384 & --- & 228 & 28 \\
\hline & & & \multirow[t]{3}{*}{ Vacuum } & 25 & 630 & -- & 560 & 530 & 36 \\
\hline & & & & 480 & 469 & --- & 398 & 382 & 33 \\
\hline & & & & 1040 & 402 & 376 & 219 & 219 & 28 \\
\hline \multirow[t]{6}{*}{1650} & 5000 & 1040 & Lithium & 25 & 638 & --- & 566 & 519 & 33 \\
\hline & & & & 760 & 416 & $\ldots$ & 311 & 299 & 25 \\
\hline & & & & 1040 & 399 & 383 & $\cdots$ & 250 & 25 \\
\hline & & & Vacuum & 480 & 487 & -- & 416 & 390 & 29 \\
\hline & & & & 760 & 391 & $\cdots$ & 314 & 289 & 30 \\
\hline & & & & 1040 & 390 & 369 & 220 & 219 & 29 \\
\hline 1650 & 1000 & 1040 & Lithium & 25 & 694 & $\cdots$ & 599 & 575 & 27 \\
\hline & & & & 760 & 434 & --- & 334 & 322 & 23 \\
\hline & & & & 1040 & 435 & 417 & $-\cdots$ & 281 & 19 \\
\hline & & & Vacuum & 480 & 453 & -- & 365 & 331 & 37 \\
\hline & & & & 760 & 412 & -- & 350 & 311 & 27 \\
\hline & & & & 1040 & 404 & 380 & 226 & 225 & 28 \\
\hline 1815 & 1000 & 1040 & Lithium & 25 & 672 & $\ldots$ & 573 & 559 & 33 \\
\hline & & & & 480 & 497 & --- & 389 & 361 & 30 \\
\hline & & & & 1040 & 423 & 401 & --- & 266 & 22 \\
\hline & & & Vacuum & 25 & 627 & -- & 544 & 518 & 36 \\
\hline & & & & 760 & 403 & -- & 283 & 262 & 24 \\
\hline & & & & 1040 & 394 & 376 & --- & 212 & 26 \\
\hline 1980 & 1000 & 1040 & Lithium & 480 & 527 & --- & -- & 414 & 27 \\
\hline & & & & 760 & 407 & --- & --- & 274 & 26 \\
\hline & & & & 1040 & 407 & 392 & --- & 247 & 23 \\
\hline & & & Vacuum & 25 & 615 & -- & 516 & 507 & 34 \\
\hline & & & & 480 & 450 & $\ldots$ & --- & 330 & 28 \\
\hline & & & & 1040 & 383 & 365 & --- & 208 & 27 \\
\hline
\end{tabular}

${ }^{\mathrm{a}}$ Or 0.2 percent offset yield stress. 
TABLE V. - Concluded. SUMMARY OF TENSILE DATA FOR T-111

(b) T-111 tube

\begin{tabular}{|c|c|c|c|c|c|c|c|c|c|}
\hline \multirow{3}{*}{$\begin{array}{c}\text { Annealing } \\
\text { temper- } \\
\text { ature, } \\
{ }^{\circ} \mathrm{C}\end{array}$} & \multicolumn{3}{|c|}{ Aging conditions } & \multirow{3}{*}{$\mid \begin{array}{c}\text { Test tem- } \\
\text { perature, } \\
{ }^{\circ} \mathrm{C}\end{array}$} & \multirow{2}{*}{\multicolumn{2}{|c|}{$\begin{array}{c}\text { Ultimate tensile stress, } \\
{ }^{\sigma} \mathrm{UTS} \\
\mathrm{MN} / \mathrm{m}^{2}\end{array}$}} & \multirow{2}{*}{\multicolumn{2}{|c|}{$\begin{array}{l}\text { Yield stress, } \\
\sigma_{\mathrm{YS}} \\
\mathrm{MN} / \mathrm{m}^{2}\end{array}$}} & \multirow{3}{*}{$\begin{array}{c}\text { Elongation, } \\
\text { percent }\end{array}$} \\
\hline & \multirow[t]{2}{*}{$\begin{array}{c}\text { Time, } \\
\mathrm{hr}\end{array}$} & \multirow{2}{*}{$\begin{array}{c}\text { Temper- } \\
\text { ature, } \\
{ }^{\circ} \mathrm{C}\end{array}$} & \multirow[t]{2}{*}{ Environment } & & & & & & \\
\hline & & & & & Maximum & Minimum & Upper & Lower $^{2}$ & \\
\hline \multirow[t]{5}{*}{1650} & --- & --- & ------ & 25 & 630 & --- & 591 & 533 & 33 \\
\hline & --- & -- & $\cdots---$ & 480 & 427 & -- & --- & 312 & 30 \\
\hline & --- & --- & $---\cdots$ & 620 & 409 & -- & -- & $31 \mathrm{C}$ & 33 \\
\hline & $\cdots$ & --- & ------ & 760 & 419 & 410 & 296 & 288 & 23 \\
\hline & --- & --- & $\cdots+-$ & 1040 & 396 & 372 & 227 & $22 ?$ & 29 \\
\hline \multirow[t]{6}{*}{1650} & \multirow[t]{6}{*}{1000} & \multirow[t]{6}{*}{925} & \multirow[t]{3}{*}{ Lithium } & 25 & 663 & -- & --- & 567 & 29 \\
\hline & & & & 480 & 502 & -- & --- & 356 & 23 \\
\hline & & & & 1040 & 529 & 510 & -- & 322 & 22 \\
\hline & & & \multirow[t]{3}{*}{ Vacuum } & 25 & 618 & -- & -- & 463 & 35 \\
\hline & & & & 760 & 462 & 447 & -- & 274 & 25 \\
\hline & & & & 1040 & 442 & 414 & -- & 267 & 25 \\
\hline \multirow[t]{6}{*}{1650} & \multirow[t]{6}{*}{1000} & \multirow[t]{6}{*}{1150} & \multirow[t]{3}{*}{ Lithium } & 480 & 462 & $\cdots$ & 345 & 326 & 29 \\
\hline & & & & 760 & 399 & -- & -- & 243 & 25 \\
\hline & & & & 1040 & 418 & 402 & -- & 241 & 23 \\
\hline & & & \multirow[t]{3}{*}{ Vacuum } & 25 & 596 & --- & --- & 458 & 36 \\
\hline & & & & 480 & 414 & --- & 313 & 290 & 33 \\
\hline & & & & 1040 & 399 & 381 & -- & 220 & 25 \\
\hline \multirow[t]{6}{*}{1650} & \multirow[t]{6}{*}{5000} & 1040 & Lithium & 25 & 649 & -- & --- & 479 & 29 \\
\hline & & & & 760 & 415 & --- & -- & 276 & 21 \\
\hline & & & & 1040 & 396 & 382 & --- & 258 & 22 \\
\hline & & & Vacuum & 480 & 414 & --- & 292 & 272 & 31 \\
\hline & & & & 760 & 384 & $-\cdot$ & -- & 226 & 24 \\
\hline & & & & 1040 & 370 & 358 & -- & 216 & 23 \\
\hline 1650 & 1000 & 1040 & Lithium & 25 & 629 & $\cdots$ & -- & 519 & 23 \\
\hline & & & & 760 & 434 & -- & $\cdots$ & 283 & 18 \\
\hline & & & & 1040 & 453 & 442 & -- & 302 & 19 \\
\hline & & & Vacuum & 480 & 427 & -- & 301 & 278 & 31 \\
\hline & & & & 760 & 399 & --- & --- & 248 & 26 \\
\hline & & & & 1040 & 400 & 381 & --- & 236 & 25 \\
\hline 1815 & 1000 & 1040 & Lithium & 25 & 725 & -- & --- & 521 & 24 \\
\hline & & & & 480 & 542 & -- & -- & 399 & 25 \\
\hline & & & & 1040 & 487 & 475 & --- & 287 & 19 \\
\hline & & & Vacuum & 25 & 656 & $\cdots$ & -- & 504 & 30 \\
\hline & & & & 760 & 481 & 466 & -- & 260 & 23 \\
\hline & & & & 1040 & 443 & 426 & --- & 241 & 24 \\
\hline 1980 & 1000 & 1040 & Lithium & 480 & 482 & -- & $\cdots$ & 334 & 24 \\
\hline & & & & 760 & 443 & --- & $\cdots$ & 270 & 22 \\
\hline & & & & 1040 & 460 & 457 & -- & 296 & 20 \\
\hline & & & Vacuum & 25 & 634 & --- & -- & 558 & 27 \\
\hline & & & & 480 & 422 & -- & -- & 277 & 29 \\
\hline & & & & 1040 & 410 & 400 & $\ldots$ & 217 & 23 \\
\hline
\end{tabular}

${ }^{\mathrm{a}}$ Or 0.2 percent offset yield stress. 
TABLE VI. - SUMMARY OF TENSILE DATA FOR MODIFIED COMPOSITION

T-111 ALLOYS, Ta-10W AND Ta-2Hf

(a) $\mathrm{Ta}-10 \mathrm{~W}$

\begin{tabular}{|c|c|c|c|c|c|c|c|}
\hline \multirow[t]{2}{*}{ Condition } & \multirow[t]{2}{*}{ Environment } & \multirow[t]{2}{*}{$\begin{array}{l}\text { Test tem- } \\
\text { perature, } \\
{ }^{\circ} \mathrm{C}\end{array}$} & \multicolumn{2}{|c|}{$\begin{array}{c}\text { Ultimate tensile stress, } \\
\qquad \sigma_{\mathrm{UTS}}, \\
\mathrm{MN} / \mathrm{m}^{2}\end{array}$} & \multicolumn{2}{|c|}{$\begin{array}{c}\text { Yield stress, } \\
{ }^{\sigma} \mathrm{YS}, \\
\mathrm{MN} / \mathrm{m}^{2}\end{array}$} & \multirow[t]{2}{*}{$\begin{array}{c}\text { Elongation, } \\
\text { percent }\end{array}$} \\
\hline & & & Maximum & Minimum & Upper & Lower $^{a}$ & \\
\hline \multirow[t]{7}{*}{ Annealed } & \multirow[t]{7}{*}{ Vacuum } & 25 & 627 & -- & 558 & 555 & 32 \\
\hline & & 480 & 534 & 527 & 364 & 349 & 18 \\
\hline & & 620 & 540 & 534 & 327 & 315 & 12 \\
\hline & & 760 & 558 & 524 & 291 & 282 & 18 \\
\hline & & 900 & 496 & -- & -- & 243 & 19 \\
\hline & & 1040 & 366 & $\ldots$ &.- & 222 & 24 \\
\hline & & 1180 & 284 & --- & -- & 192 & 30 \\
\hline \multirow[t]{8}{*}{ Aged $^{c}$} & \multirow[t]{4}{*}{ Lithium } & 25 & 582 & -. & 492 & 482 & 27 \\
\hline & & 480 & 376 & -- & --- & 268 & 22 \\
\hline & & 760 & 399 & 379 &.-- & 205 & 16 \\
\hline & & 1040 & 277 & -- & -- & 172 & 24 \\
\hline & \multirow[t]{4}{*}{ Vacuum } & 25 & 610 & --- & 546 & 514 & 28 \\
\hline & & 480 & 458 &.- & 332 & 319 & 19 \\
\hline & & 760 & 457 & 439 & 245 & 234 & 20 \\
\hline & & 1040 & 308 & -- &.- & 186 & 26 \\
\hline
\end{tabular}

(b) Ta-8W-0.5Hf

\begin{tabular}{|c|c|c|c|c|c|c|c|}
\hline Annealed & Vacuum & $\begin{array}{r}25 \\
480 \\
620 \\
760 \\
900 \\
1040 \\
1180\end{array}$ & $\begin{array}{l}523 \\
340 \\
332 \\
330 \\
308 \\
267 \\
230\end{array}$ & $\begin{array}{l}--. \\
--- \\
322 \\
322 \\
301 \\
--- \\
---\end{array}$ & $\begin{array}{l}434 \\
267 \\
208 \\
--- \\
--- \\
--- \\
---\end{array}$ & $\begin{array}{l}429 \\
259 \\
205 \\
165 \\
156 \\
145 \\
138\end{array}$ & $\begin{array}{l}36 \\
35 \\
19 \\
23 \\
29 \\
35 \\
35\end{array}$ \\
\hline \multirow[t]{2}{*}{ Aged } & Lithium & $\begin{array}{r}25 \\
480 \\
760 \\
1040\end{array}$ & $\begin{array}{l}521 \\
340 \\
323 \\
263\end{array}$ & $\begin{array}{l}--- \\
--- \\
318 \\
---\end{array}$ & $\begin{array}{c}427 \\
--- \\
167 \\
---\end{array}$ & $\begin{array}{l}418 \\
257 \\
165 \\
143\end{array}$ & $\begin{array}{l}34 \\
32 \\
26 \\
30\end{array}$ \\
\hline & Vacuum & $\begin{array}{r}25 \\
480 \\
760 \\
1040\end{array}$ & $\begin{array}{l}523 \\
361 \\
351 \\
279\end{array}$ & $\begin{array}{l}--- \\
--- \\
339 \\
---\end{array}$ & $\begin{array}{l}436 \\
291 \\
--- \\
---\end{array}$ & $\begin{array}{l}429 \\
273 \\
166 \\
148\end{array}$ & $\begin{array}{l}35 \\
30 \\
27 \\
24\end{array}$ \\
\hline
\end{tabular}

(c) Ta-8W-1Hf

\begin{tabular}{|c|c|c|c|c|c|c|c|}
\hline Annealed & Vacuum & $\begin{array}{r}25 \\
480 \\
620 \\
760 \\
900 \\
1040 \\
1180\end{array}$ & $\begin{array}{l}532 \\
333 \\
332 \\
349 \\
311 \\
284 \\
258\end{array}$ & $\begin{array}{l}--- \\
--- \\
--- \\
336 \\
303 \\
--- \\
---\end{array}$ & $\begin{array}{l}462 \\
254 \\
221 \\
-.- \\
--- \\
--- \\
-.-\end{array}$ & $\begin{array}{l}445 \\
250 \\
220 \\
178 \\
154 \\
165 \\
168\end{array}$ & $\begin{array}{l}37 \\
33 \\
24 \\
28 \\
31 \\
29 \\
21\end{array}$ \\
\hline Aged & Lithium & $\begin{array}{r}25 \\
480 \\
760 \\
1040\end{array}$ & $\begin{array}{l}527 \\
334 \\
322 \\
285\end{array}$ & $\begin{array}{l}--- \\
--- \\
322 \\
277\end{array}$ & $\begin{array}{l}429 \\
248 \\
-\cdots \\
---\end{array}$ & $\begin{array}{l}425 \\
291 \\
179 \\
153\end{array}$ & $\begin{array}{l}36 \\
36 \\
26 \\
26\end{array}$ \\
\hline & Vacuum & $\begin{array}{r}25 \\
480 \\
760 \\
1040\end{array}$ & $\begin{array}{l}538 \\
341 \\
343 \\
293\end{array}$ & $\begin{array}{l}--- \\
--- \\
336 \\
288\end{array}$ & $\begin{array}{l}445 \\
254 \\
193 \\
-\end{array}$ & $\begin{array}{l}435 \\
251 \\
183 \\
168\end{array}$ & $\begin{array}{l}35 \\
30 \\
24 \\
27\end{array}$ \\
\hline
\end{tabular}

${ }^{a}$ Or 0.2 percent offset yield stress.

${ }^{\mathrm{b}}$ Annealed $1 \mathrm{hr}$ at $1650^{\circ} \mathrm{C}$.

$\mathrm{c}_{\text {Aged }} 1000 \mathrm{hr}$ at $1040^{\circ} \mathrm{C}$. 
TABLE VI. - Concluded. SUMMARY OF TENSILE DATA FOR MODIFIED

COMPOSTTION T-111 ALLOYS, Ta-10W AND Ta-2Hf

(d) $\mathrm{Ta}-8 \mathrm{~W}-3 \mathrm{H} f$

\begin{tabular}{|c|c|c|c|c|c|c|c|}
\hline \multirow[t]{2}{*}{ Condition } & \multirow[t]{2}{*}{ Environment } & \multirow[t]{2}{*}{$\begin{array}{l}\text { Test tem- } \\
\text { perature, } \\
{ }^{\circ} \mathrm{C}\end{array}$} & \multicolumn{2}{|c|}{$\begin{array}{l}\text { Ultimate tensile stress, } \\
\text { 'UTS' } \\
\mathrm{MN} / \mathrm{m}^{2}\end{array}$} & \multicolumn{2}{|c|}{$\begin{array}{c}\text { Yield stress, } \\
{ }^{\sigma} \mathrm{YS}{ }^{\prime} \\
\mathrm{MN} / \mathbf{m}^{2}\end{array}$} & \multirow[t]{2}{*}{$\begin{array}{l}\text { Elongation, } \\
\text { percent }\end{array}$} \\
\hline & & & Maximum & Minimum & Upper & Lower ${ }^{2}$ & \\
\hline \multirow[t]{7}{*}{ Annealed } & \multirow[t]{7}{*}{ Vacuum } & 25 & 590 & -- & 525 & 507 & 32 \\
\hline & & 480 & 421 & -- & 369 & 342 & 35 \\
\hline & & 620 & 410 & $\cdots$ & 295 & 283 & 25 \\
\hline & & 760 & 418 & 407 & 261 & 254 & 25 \\
\hline & & 900 & 399 & 383 & 248 & 236 & 24 \\
\hline & & 1040 & 387 & $\cdots$ & -- & 213 & 25 \\
\hline & & 1180 & 320 & --- & $-=-$ & 196 & 36 \\
\hline \multirow[t]{8}{*}{ Aged } & \multirow[t]{4}{*}{ Lithium } & 25 & 608 & --- & 521 & 518 & 34 \\
\hline & & 480 & 405 & -- & 334 & 321 & 34 \\
\hline & & 760 & 392 & 391 & $\cdots$ & 262 & 23 \\
\hline & & 1090 & 363 & 362 & $-\cdots$ & 204 & 26 \\
\hline & \multirow[t]{4}{*}{ Vacuum } & 25 & 605 & --- & 554 & 507 & 33 \\
\hline & & 480 & 416 & 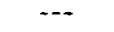 & 341 & 332 & 32 \\
\hline & & 760 & 397 & 388 & 263 & 249 & 22 \\
\hline & & 1040 & 380 & -- & $\ldots$ & 203 & 25 \\
\hline
\end{tabular}

(e) Ta-4W-2Hf

\begin{tabular}{|c|c|c|c|c|c|c|c|}
\hline Annealed & Vacuum & $\begin{array}{r}25 \\
480 \\
620 \\
760 \\
900 \\
1040 \\
1180\end{array}$ & $\begin{array}{l}434 \\
298 \\
305 \\
311 \\
294 \\
268 \\
229\end{array}$ & $\begin{array}{l}--- \\
--- \\
301 \\
304 \\
288 \\
--- \\
---\end{array}$ & $\begin{array}{c}358 \\
231 \\
--- \\
160 \\
--- \\
--- \\
---\end{array}$ & $\begin{array}{l}344 \\
203 \\
16 i \\
159 \\
134 \\
132 \\
122\end{array}$ & $\begin{array}{l}38 \\
32 \\
21 \\
28 \\
32 \\
30 \\
43\end{array}$ \\
\hline \multirow[t]{2}{*}{ Aged } & Lithium & $\begin{array}{r}25 \\
480 \\
760 \\
1040\end{array}$ & $\begin{array}{l}436 \\
289 \\
296 \\
267\end{array}$ & $\begin{array}{l}\cdots- \\
290 \\
256\end{array}$ & $\begin{array}{c}350 \\
--- \\
--- \\
---\end{array}$ & $\begin{array}{l}330 \\
195 \\
151 \\
132\end{array}$ & $\begin{array}{l}36 \\
34 \\
31 \\
26\end{array}$ \\
\hline & vacuum & $\begin{array}{r}25 \\
480 \\
760 \\
1040\end{array}$ & $\begin{array}{l}434 \\
312 \\
294 \\
269\end{array}$ & $\begin{array}{l}--- \\
--- \\
288 \\
260\end{array}$ & $\begin{array}{l}336 \\
233 \\
150 \\
--\end{array}$ & $\begin{array}{l}322 \\
214 \\
150 \\
129\end{array}$ & $\begin{array}{l}44 \\
37 \\
29 \\
28\end{array}$ \\
\hline
\end{tabular}

(f) Ta-2Hf

\begin{tabular}{|c|c|c|c|c|c|c|c|}
\hline Annealed & Vacuum & $\begin{array}{r}25 \\
480 \\
620 \\
760 \\
900 \\
1040 \\
1180\end{array}$ & $\begin{array}{l}299 \\
221 \\
276 \\
248 \\
245 \\
234 \\
193\end{array}$ & $\begin{array}{l}--- \\
--- \\
273 \\
241 \\
240 \\
225 \\
---\end{array}$ & $\begin{array}{c}263 \\
--- \\
--- \\
108 \\
101 \\
--- \\
---\end{array}$ & $\begin{array}{r}231 \\
139 \\
115 \\
102 \\
99 \\
101 \\
99\end{array}$ & $\begin{array}{l}28 \\
29 \\
19 \\
22 \\
20 \\
16 \\
19\end{array}$ \\
\hline Aged & Lithium & $\begin{array}{r}25 \\
480 \\
760 \\
1040\end{array}$ & $\begin{array}{l}299 \\
214 \\
214 \\
201\end{array}$ & $\begin{array}{l}--- \\
--- \\
211 \\
197\end{array}$ & -- & $\begin{array}{l}83 \\
99 \\
83 \\
93\end{array}$ & $\begin{array}{l}29 \\
25 \\
19 \\
21\end{array}$ \\
\hline & Vacuum & $\begin{array}{r}25 \\
480 \\
760 \\
1040\end{array}$ & $\begin{array}{l}295 \\
224 \\
219 \\
209\end{array}$ & $\begin{array}{l}-\cdots \\
-2- \\
217 \\
204\end{array}$ & $\begin{array}{r}0 .- \\
110 \\
87\end{array}$ & $\begin{array}{r}174 \\
104 \\
86 \\
90\end{array}$ & $\begin{array}{l}35 \\
23 \\
20 \\
22\end{array}$ \\
\hline
\end{tabular}

${ }^{\mathrm{a}}$ Or 0.2 percent yield stress. 


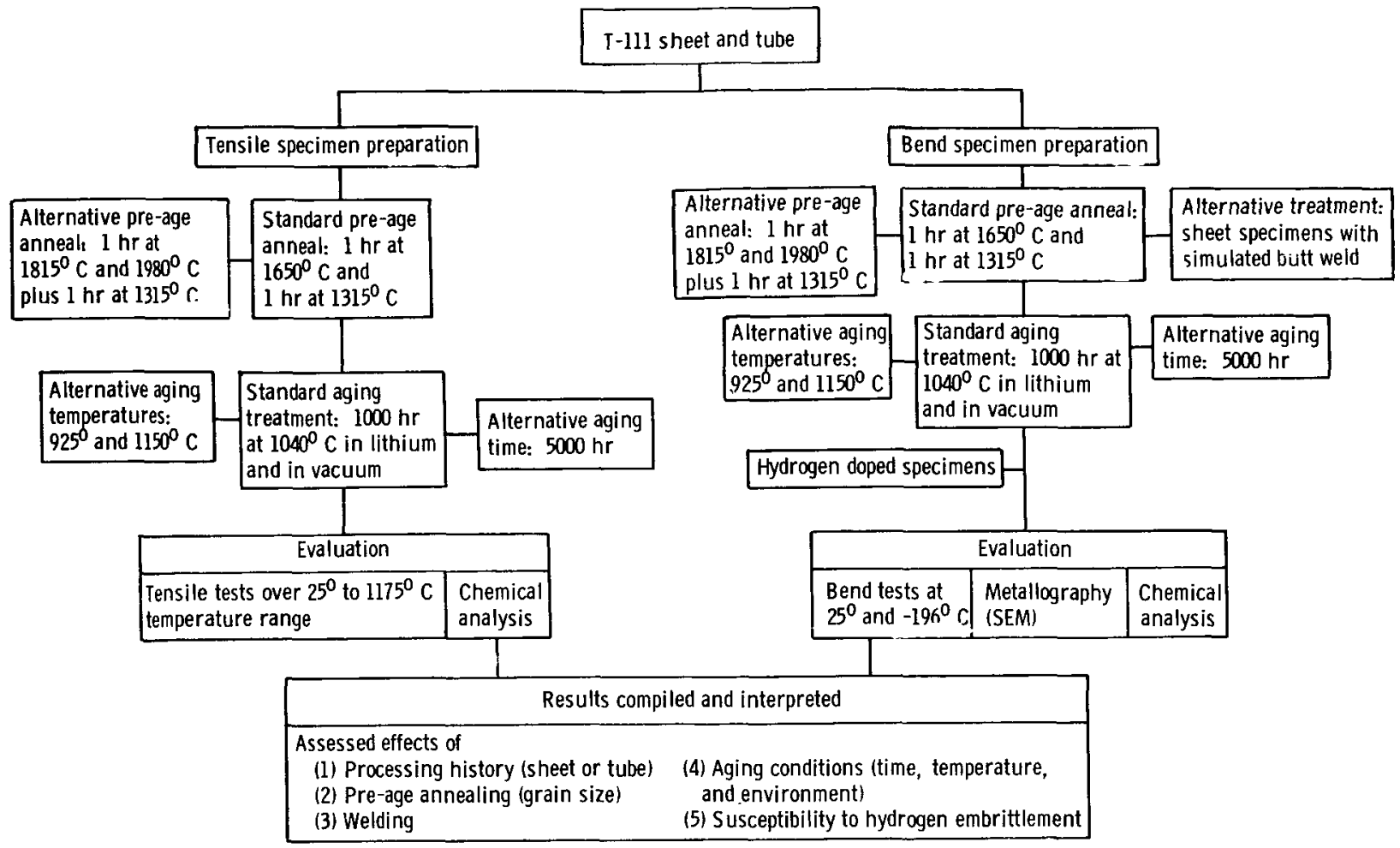

(a) T-11l study.

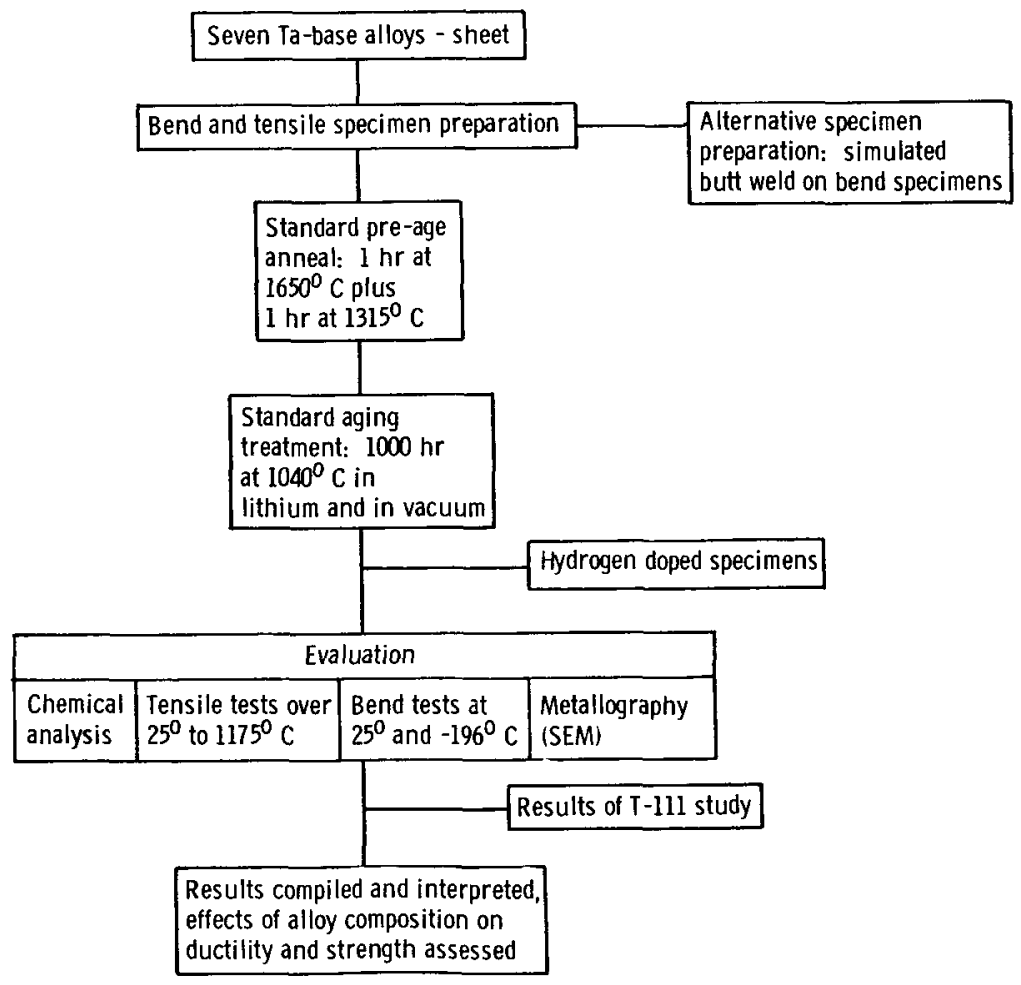

(b) Modified composition alloy study.

Figure 1. - Summary of experimental program. 


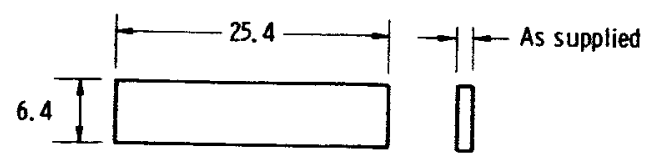

(a) Sheet bend specimen.

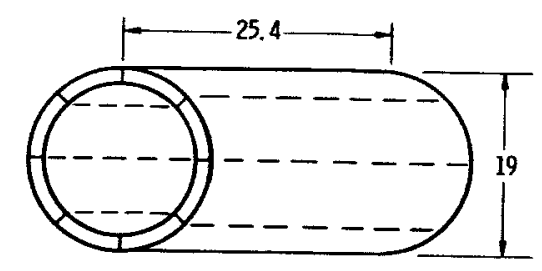

(b) Tube section bend test specimen.

Tube is slit lengthwise into eights.

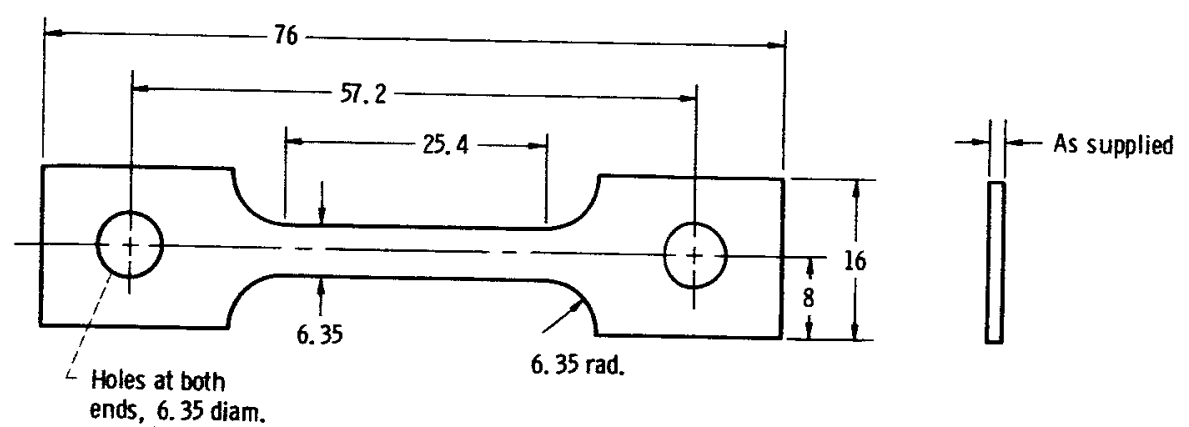

(c) Sheet tensile test specimen.

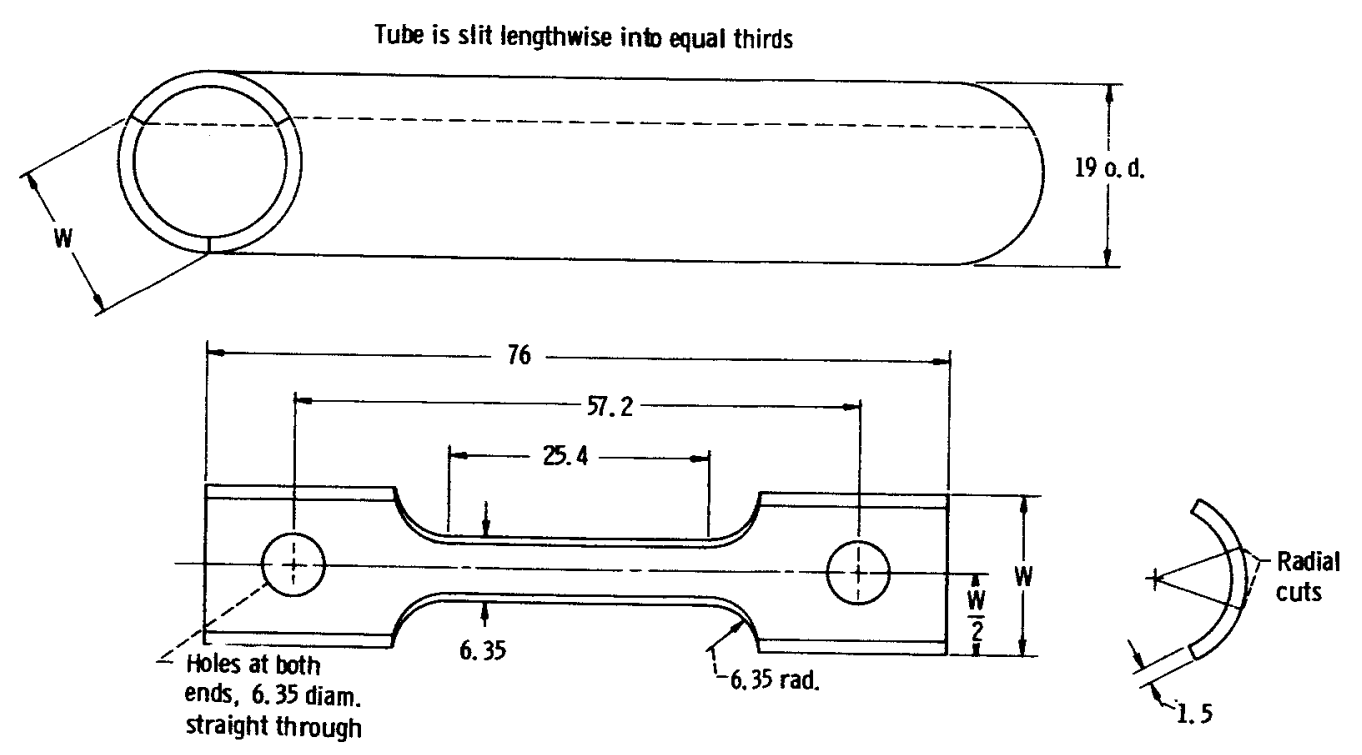

(d) Tube-section tensile test specimen.

Figure 2. - Design of test specimens. (Dimensions are in $\mathrm{mm}$. ) 

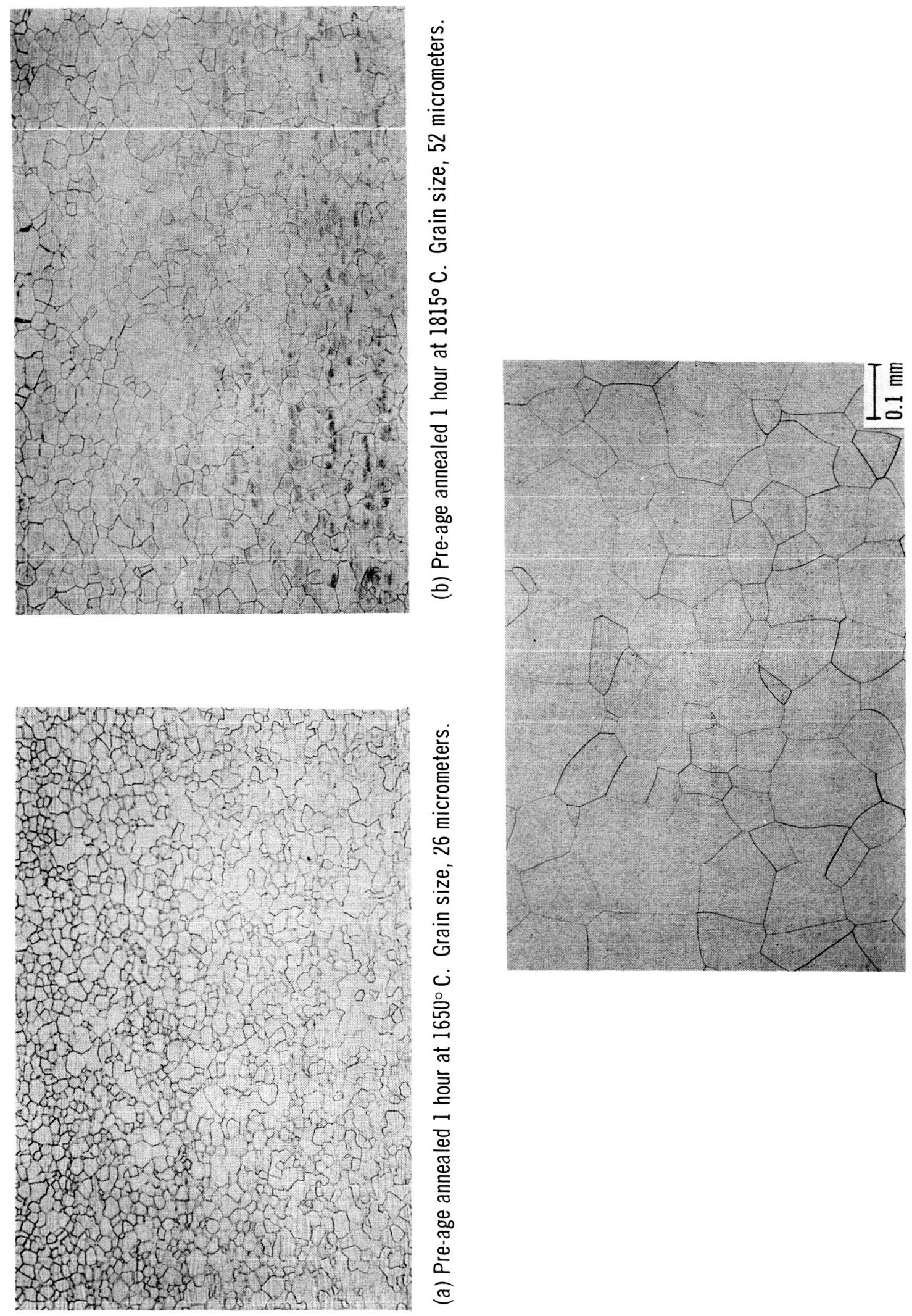

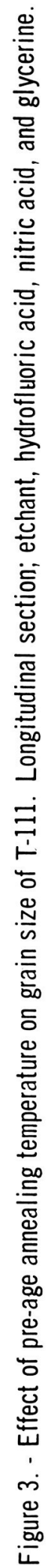




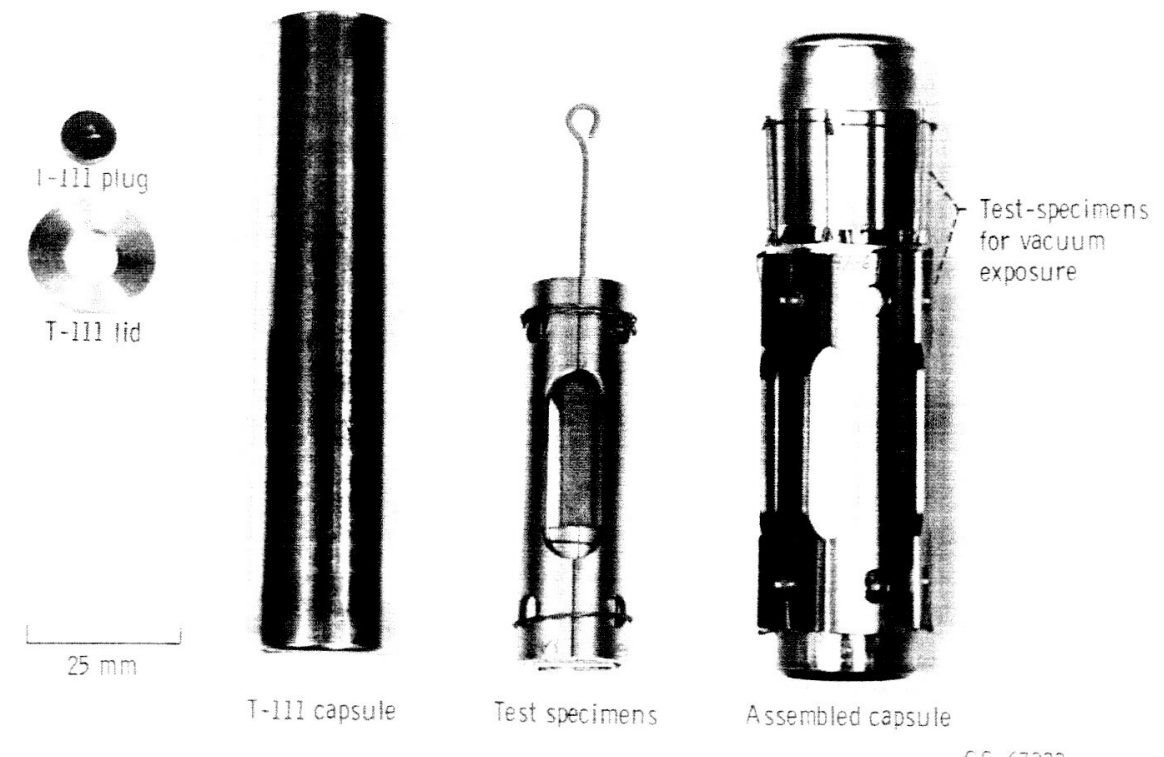

Figure 4. - Specimens and capsules for aging and hydrogen embrittlement study.

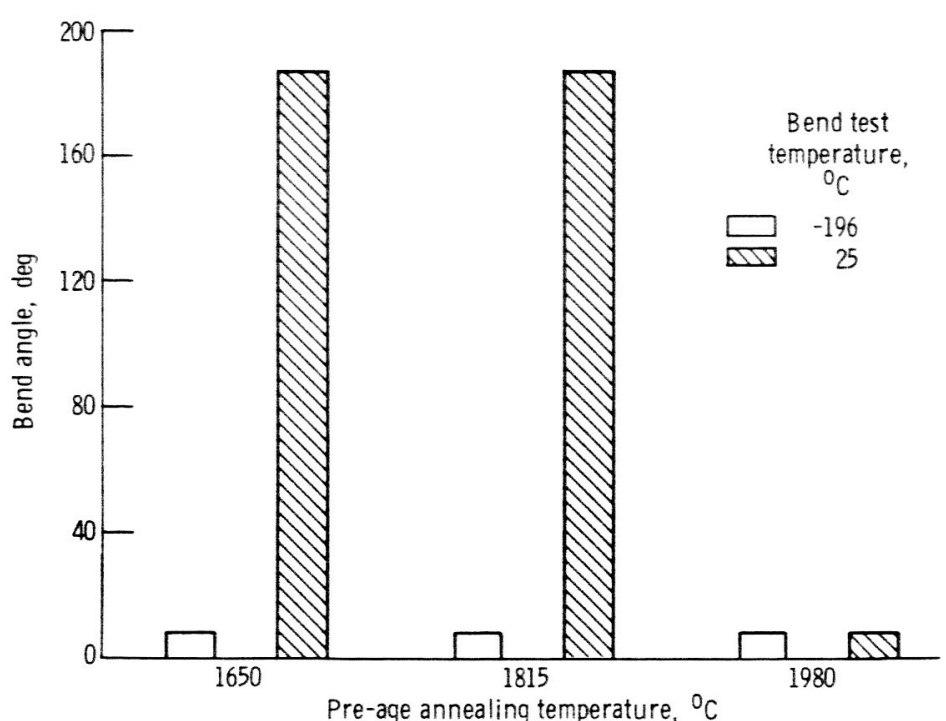

Figure 5. - Effect of pre-age annealing temperature on bend ductility of $\mathrm{T}-111$ tube aged in lithium at $1040^{\circ} \mathrm{C}$ for 1000 hours.

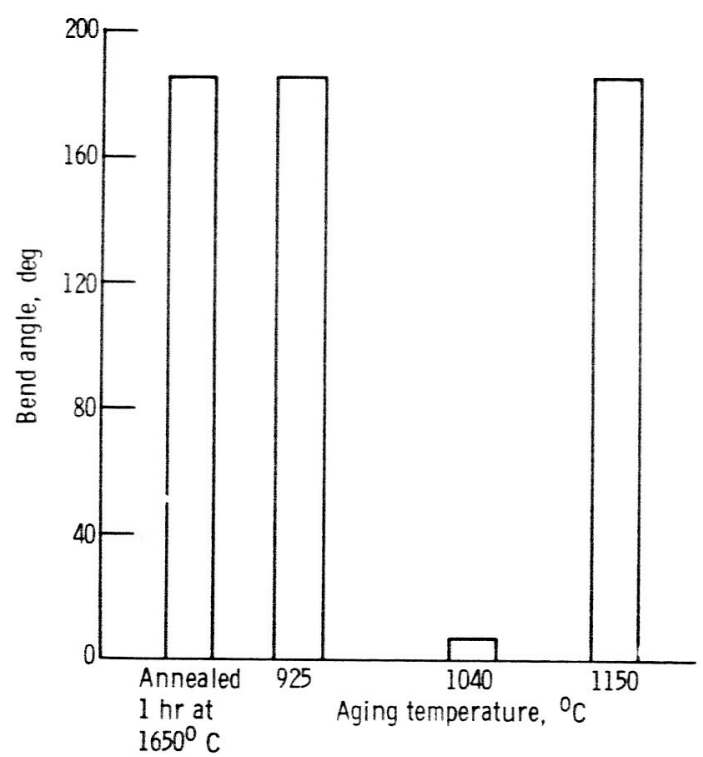

Figure 6. - Effect of aging temperature on bend ductility of T-111 tube aged in vacuum or lithium for 1000 hours. 


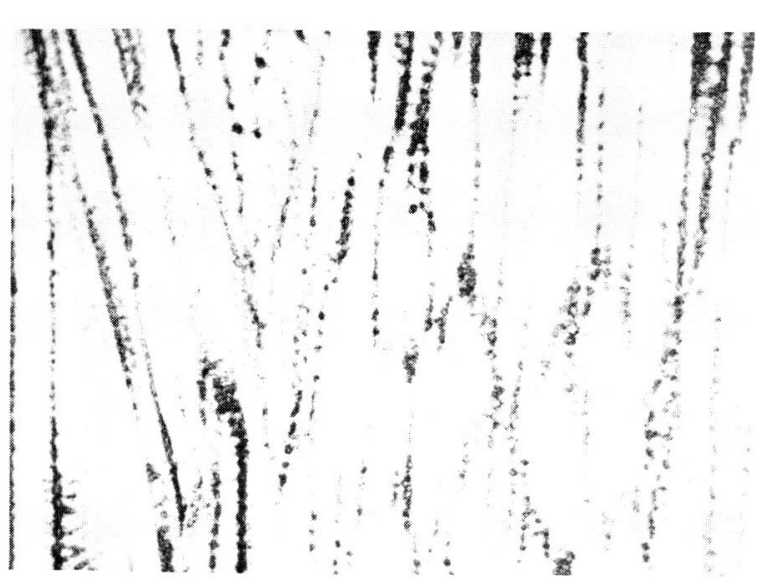

(a) Weld area.

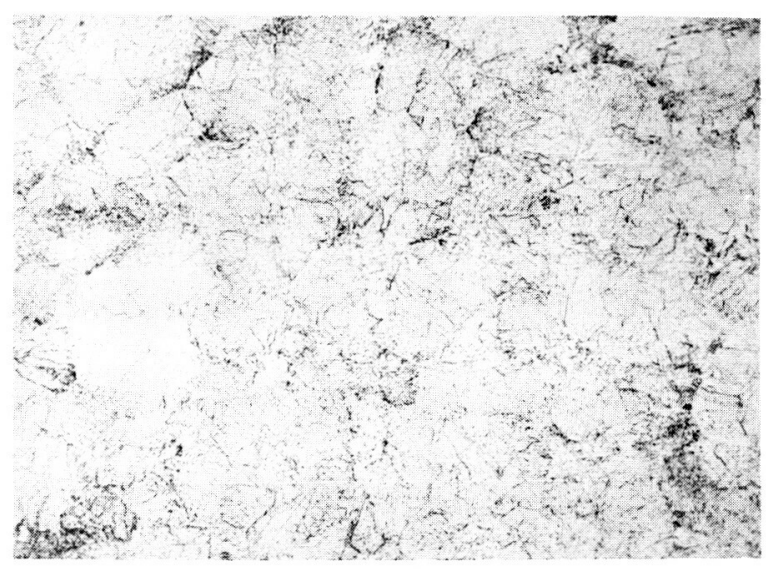

(b) Heat affected zone

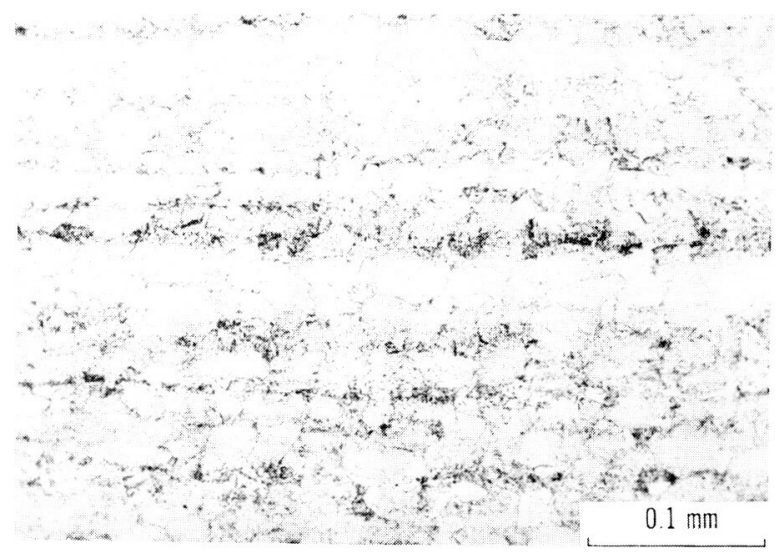

(c) Base metal.

Figure 7. - "!eld structure observed in T-111 alloy sheet after aging 1000 hours at $1040^{\circ} \mathrm{C}$. Transverse section; etchant, hydrofluoric acid, nitric acid, and glycerine. 


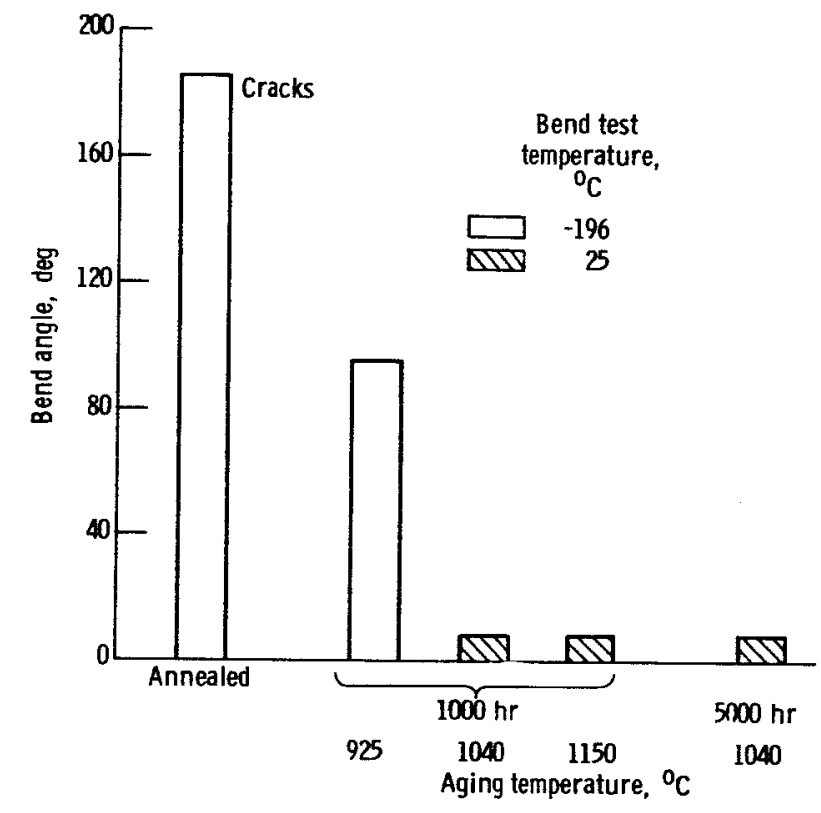

Figure 8. - Effect of hydrogen doping $(10 \mathrm{ppm} \mathrm{H})$ on bend ductility of T-111 sheet.

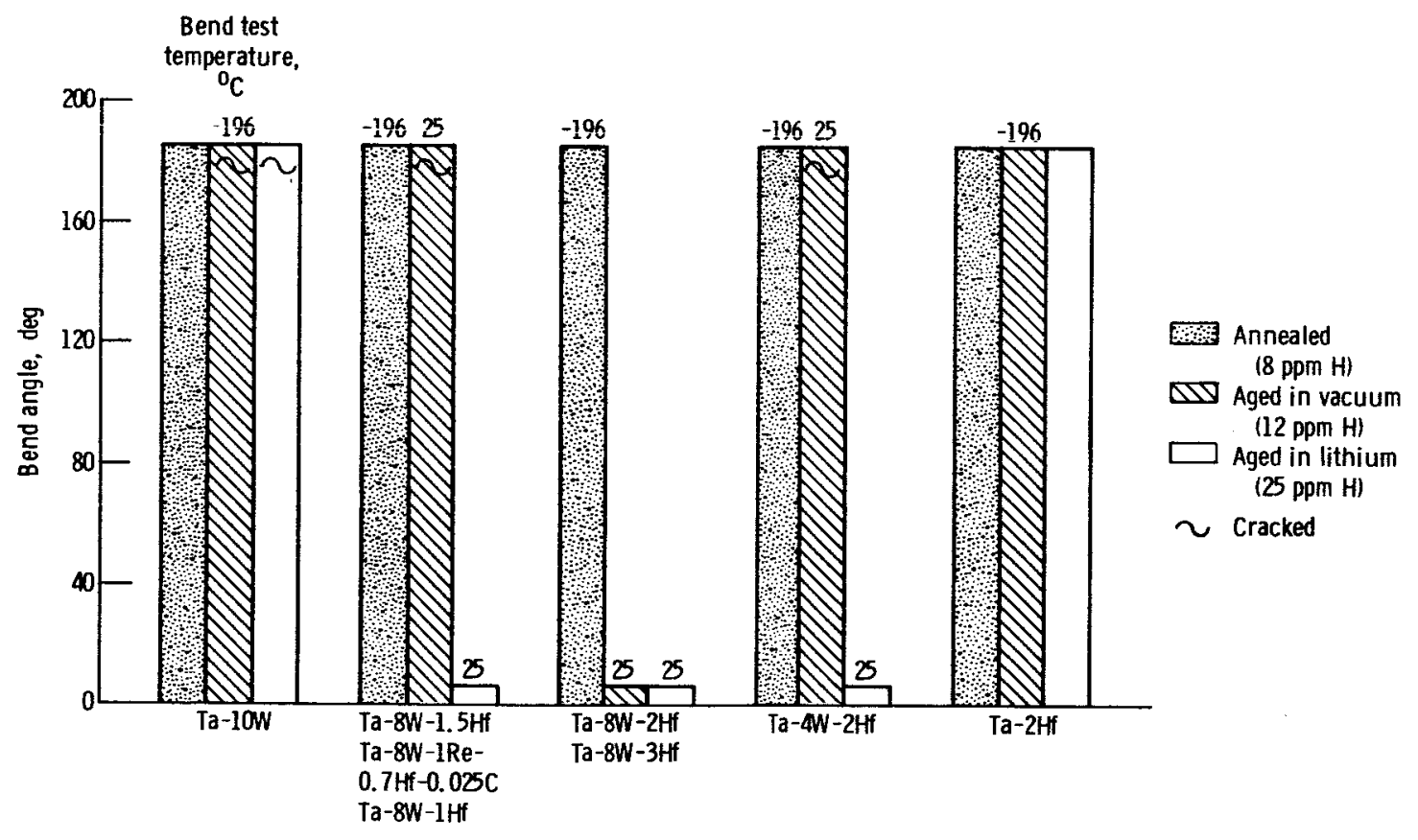

Figure 9. - Effect of hydrogen doping on bend ductility of annealed 1000 hour at $1040^{\circ} \mathrm{C}$ and aged tantalum base alloys. 


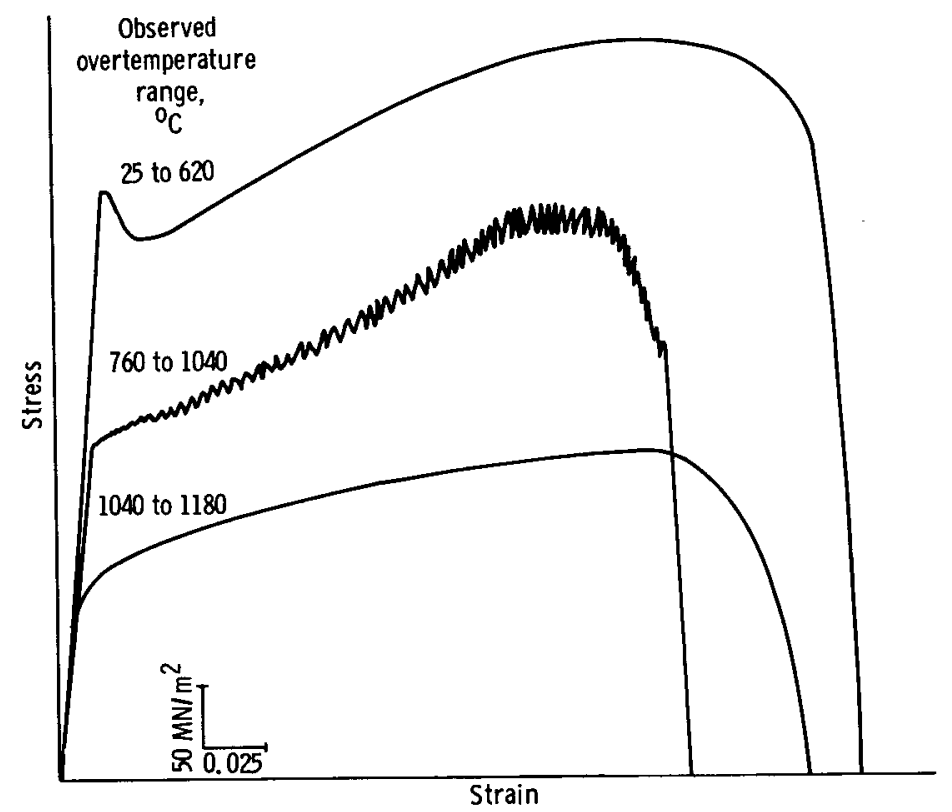

Figure 10. - Generalized engineering stress-strain curves for tantalum base alloys illustrating three types of flow behavior normally observed.

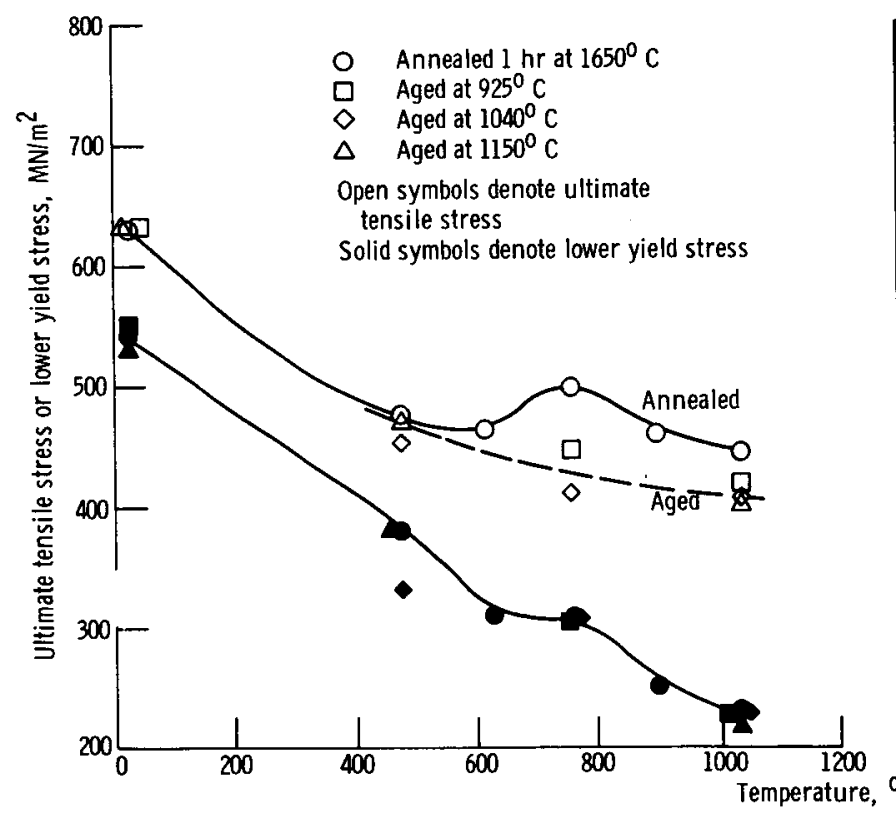

(a) Aged in vacuum.

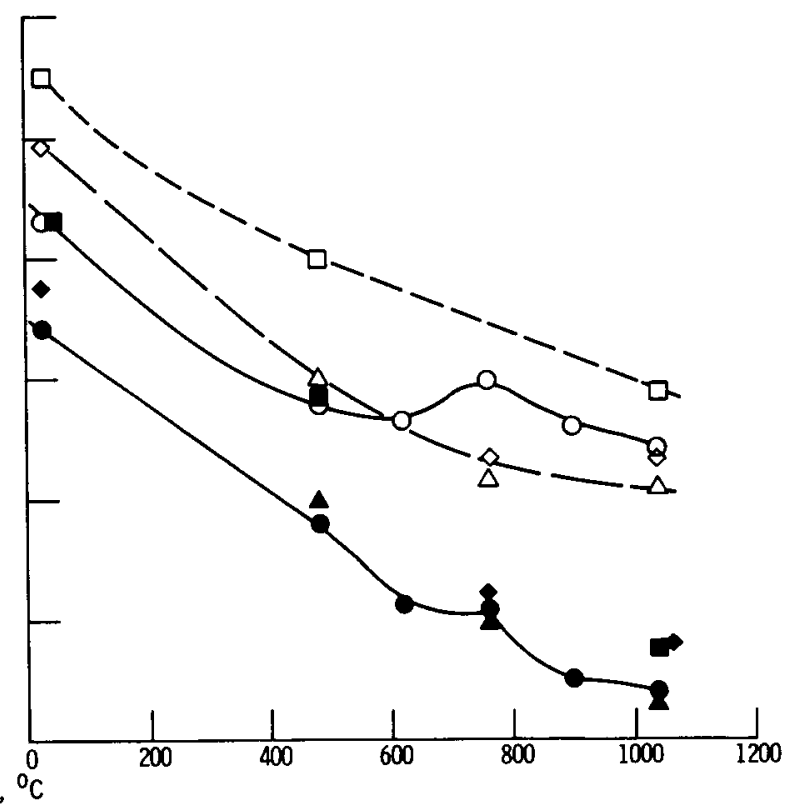

(b) Aged in lithium for 1000 hours.

Figure 11. - Effect of aging temperature on ultimate tensile stress and lower yield stress of T-11l sheet. 


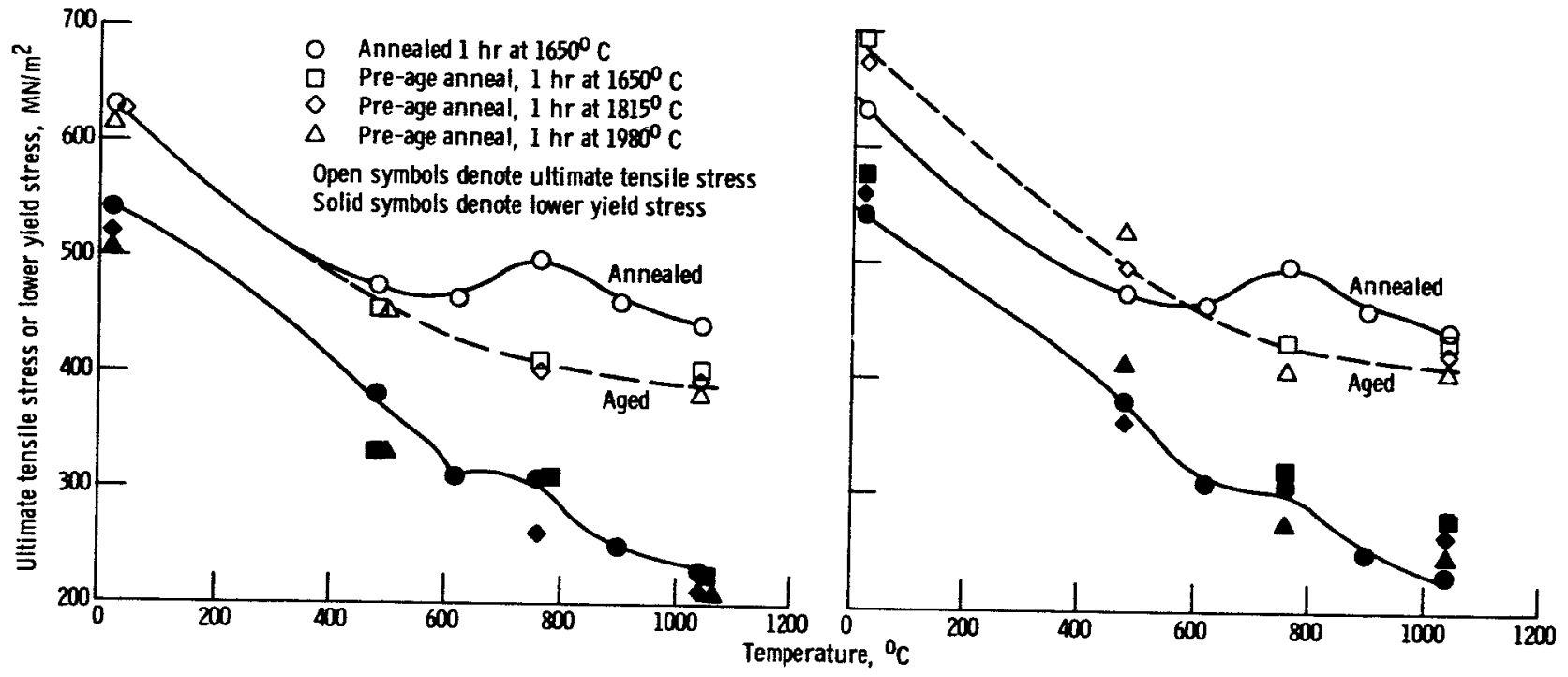

(a) Aged in vacuum at $1040^{\circ} \mathrm{C}$ for 1000 hours.

(b) Aged in lithium at $1040^{\circ} \mathrm{C}$ for 1000 hours.

Figure 12. - Effect of pre-age annealing temperature on ultimate tensile stress and lower yield stress of T-111 sheet.

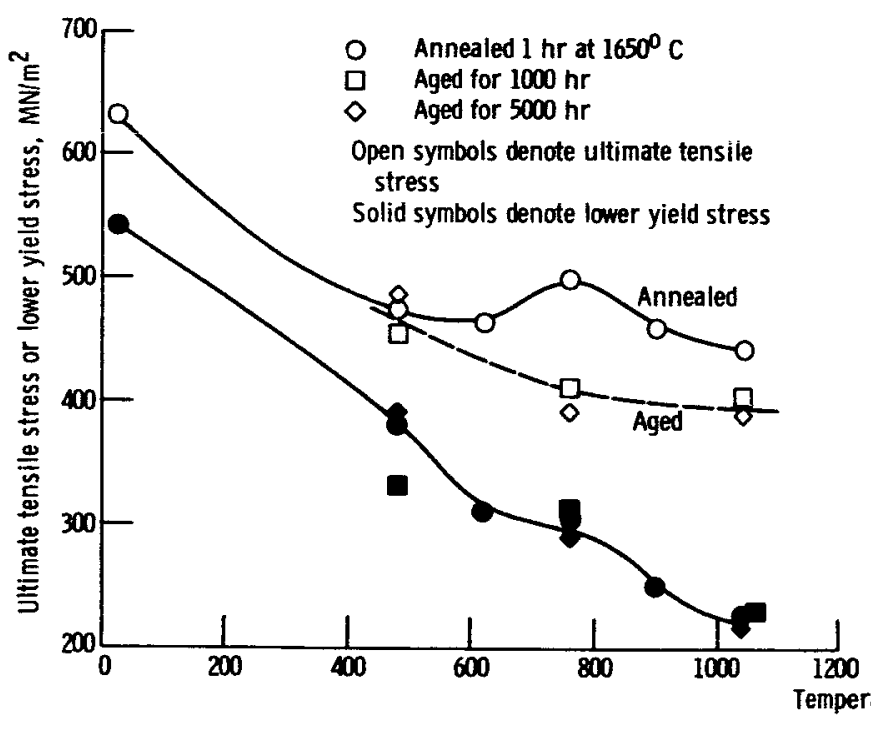

(a) Aged in vacuum.

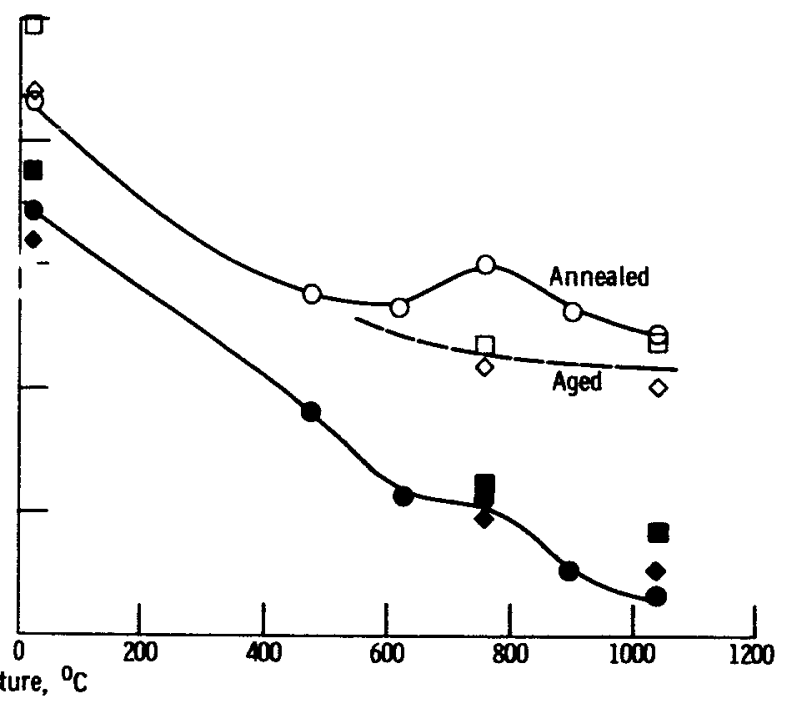

(b) Aged in lithium.

Figure 13. - Effect of aging time at $1040^{\circ} \mathrm{C}$ on ultimate tensile stress and lower yield stress of T-111 sheet. 

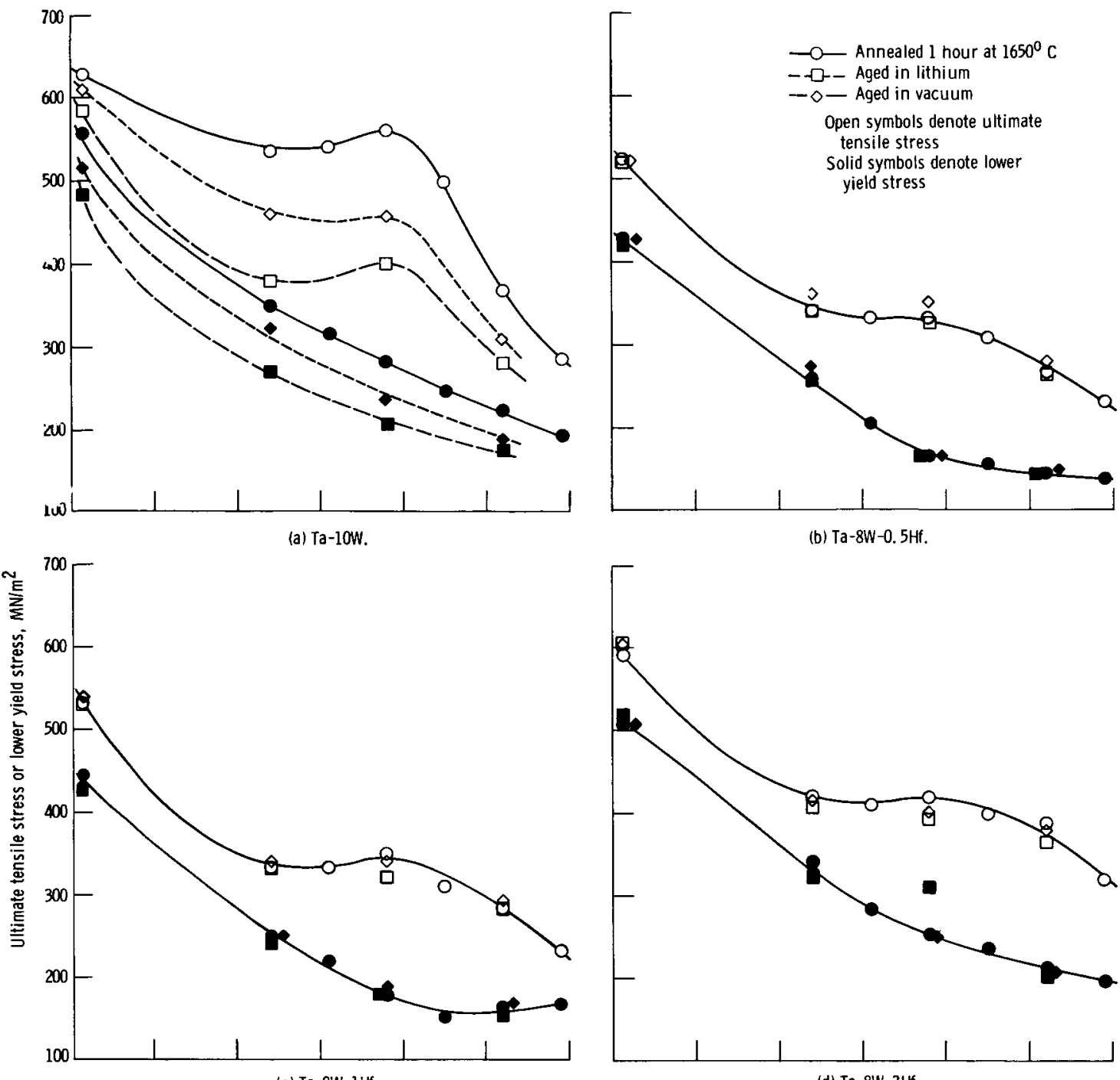

(b) Ta-8W-0. 5Hf.

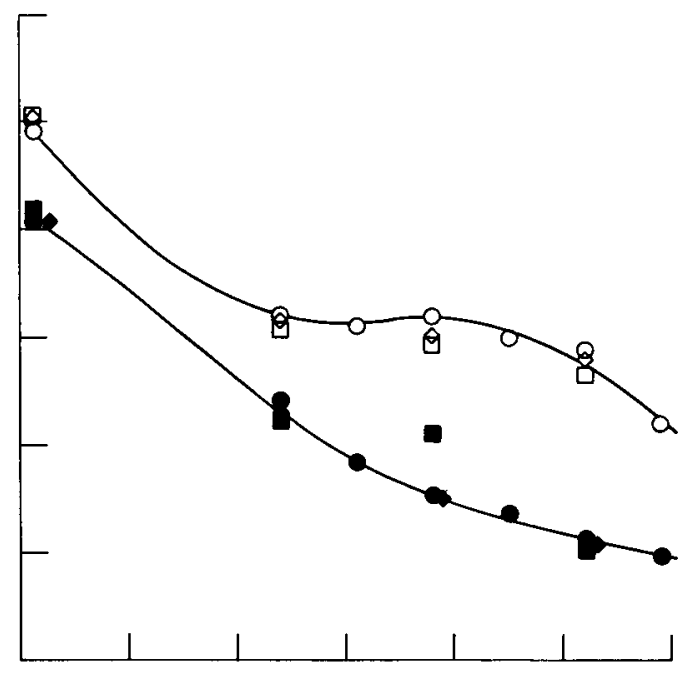

(d) Ta-8W-3Hf.
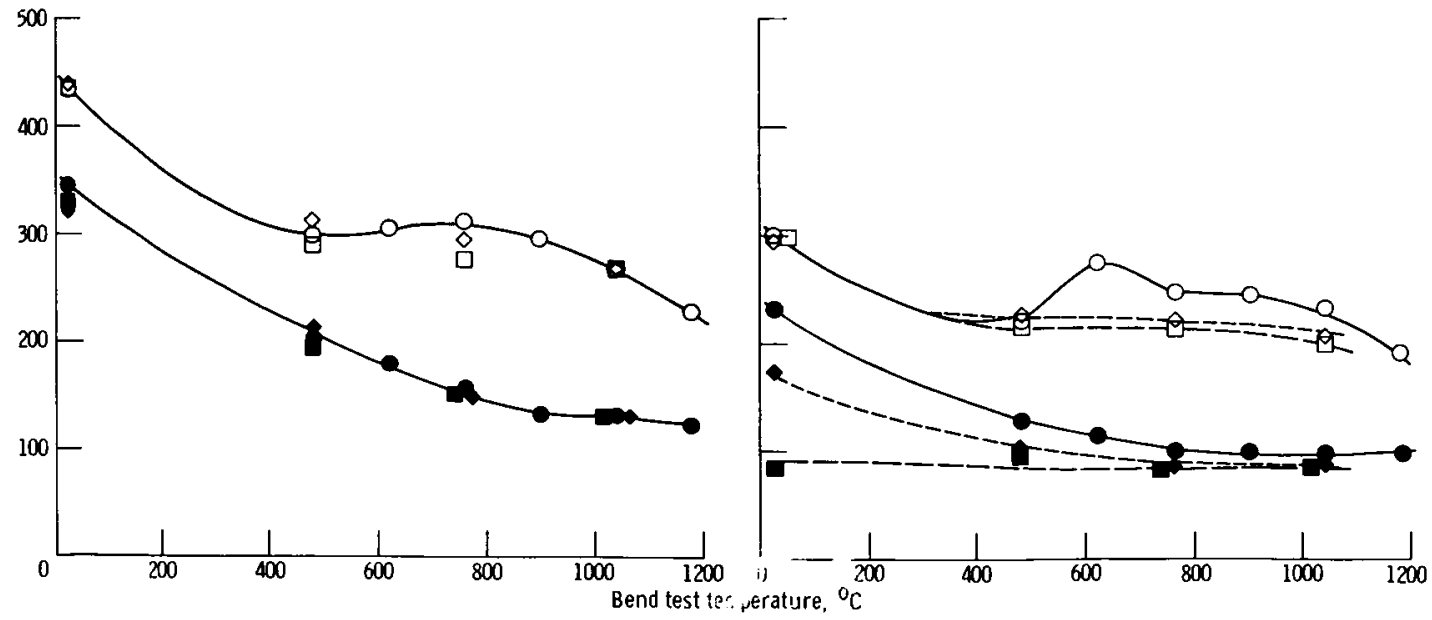

(e) Ta-4W-2Hf.

(f) Ta-2Hf.

Figure 14. - Effect of aging 1000 hours at $1040^{\circ} \mathrm{C}$ on ultimate tensile stress and lower yield stress of tantalum alloys. 


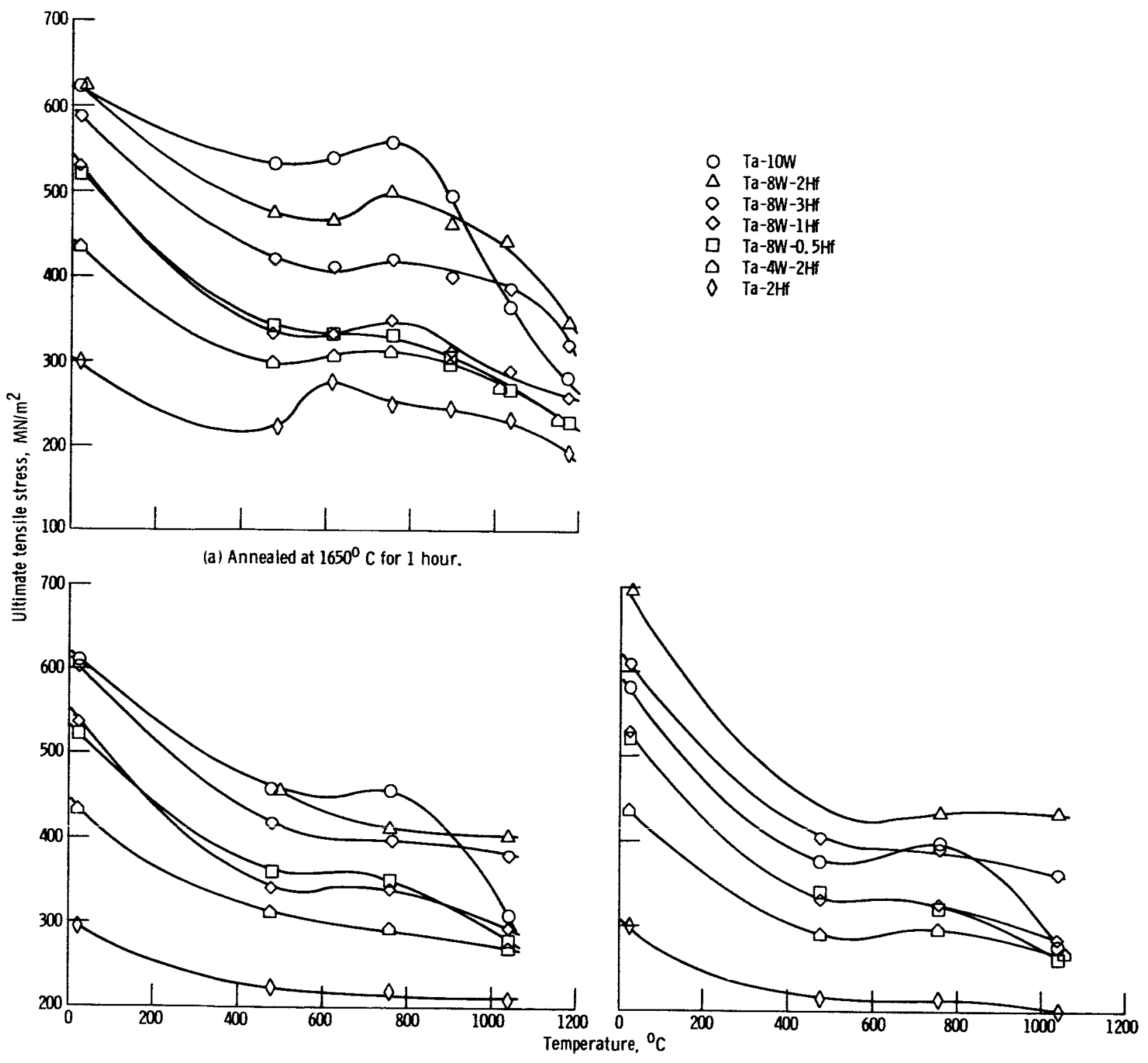

(b) Aged in vacuum at $1040^{\circ} \mathrm{C}$ for 1000 hours.

(c) Aged in lithium at $1040^{\circ} \mathrm{C}$ for 1000 hours.

Figure 15. - Comparison of temperature dependency of ultimate tensile stress of tantalum alloys. 


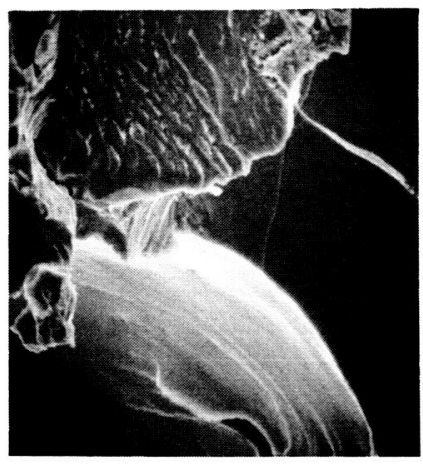

(a) Ta-10W.

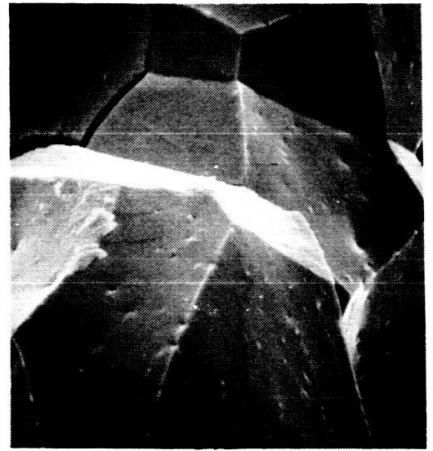

(d) Ta-8W-lHf.

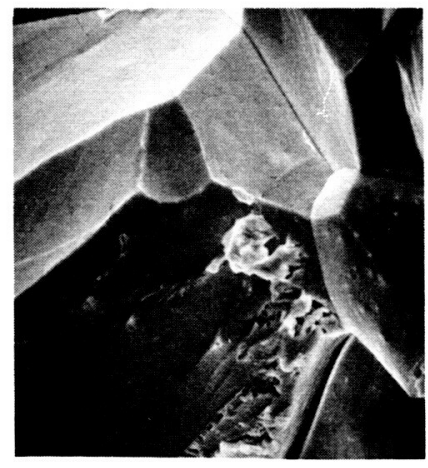

(b) Ta-8W-0.5Hf.

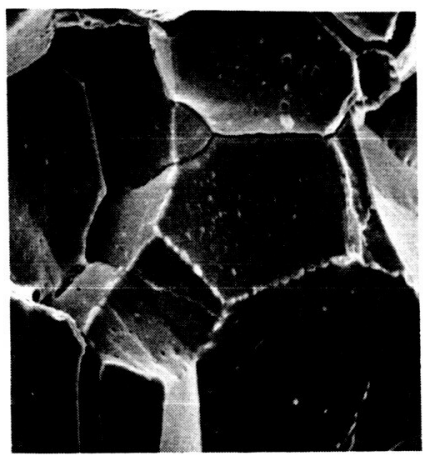

(e) Ta-8W-2Hf.

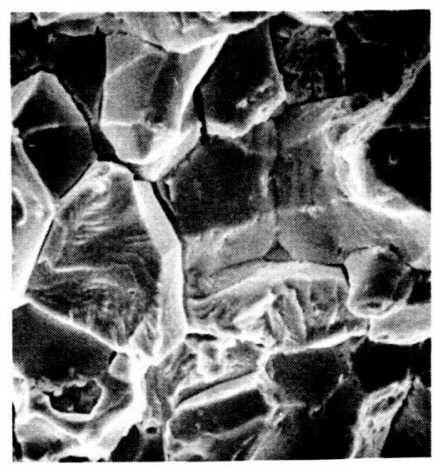

(c) Ta-8W-1Re-0.7Hf $-0.025 \mathrm{C}$.

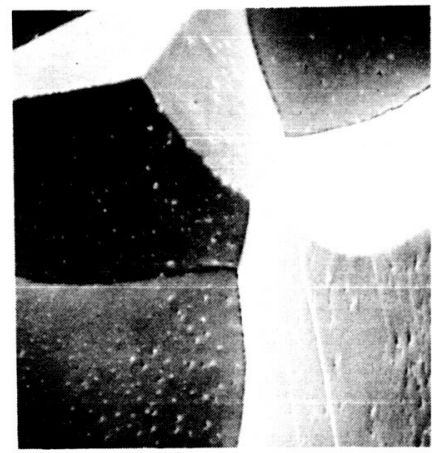

(f) Ta-8W-3Hf.

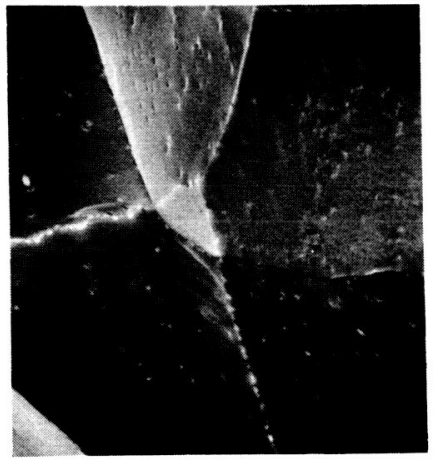

(g) Ta-4W-2Hf.

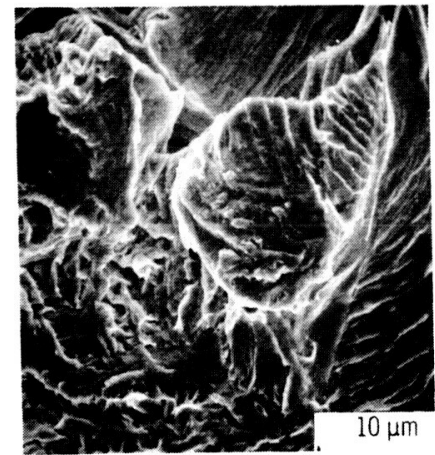

(h) Ta-2Hf.

Figure 16. - Scanning electron micrograph of fractured surfaces of tantalum-base alloys aged 1000 hours at $1040^{\circ} \mathrm{C}$. Hydrogen doped; bend tested temperature, $25^{\circ} \mathrm{C}$. 


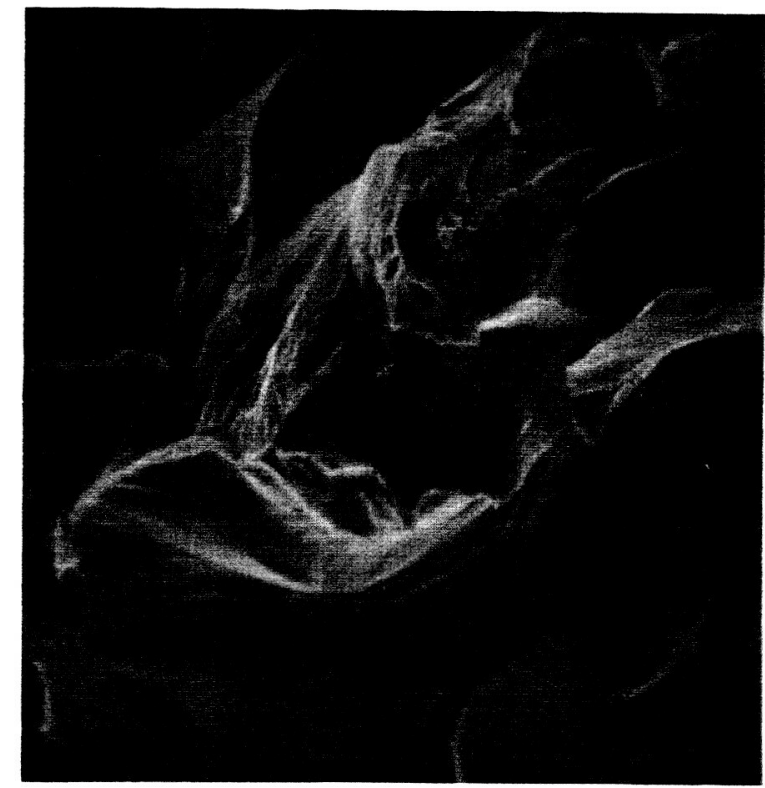

(a) Aged at $925^{\circ} \mathrm{C}$.

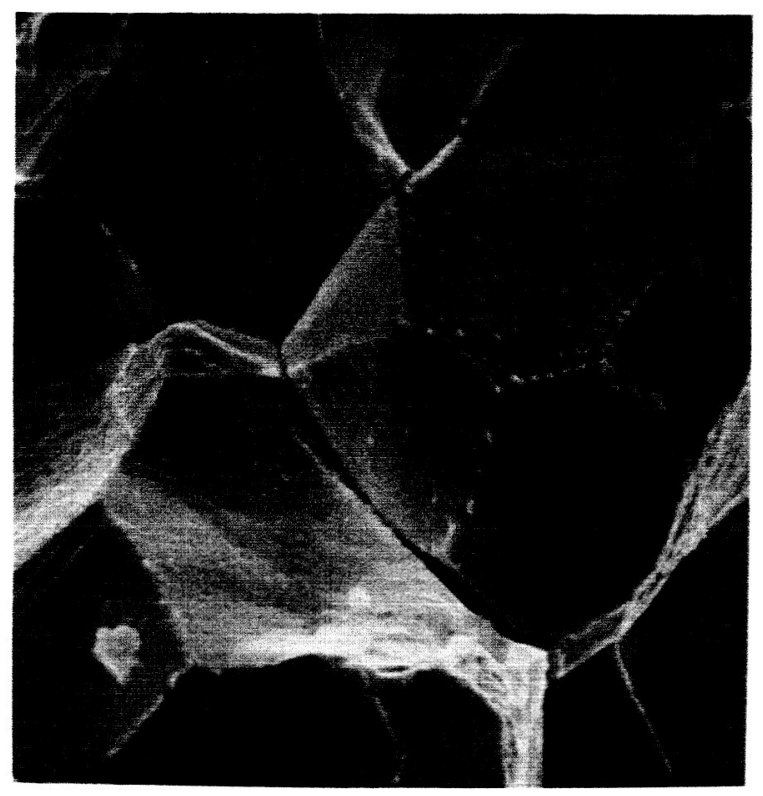

(b) Aged at $1040^{\circ} \mathrm{C}$.

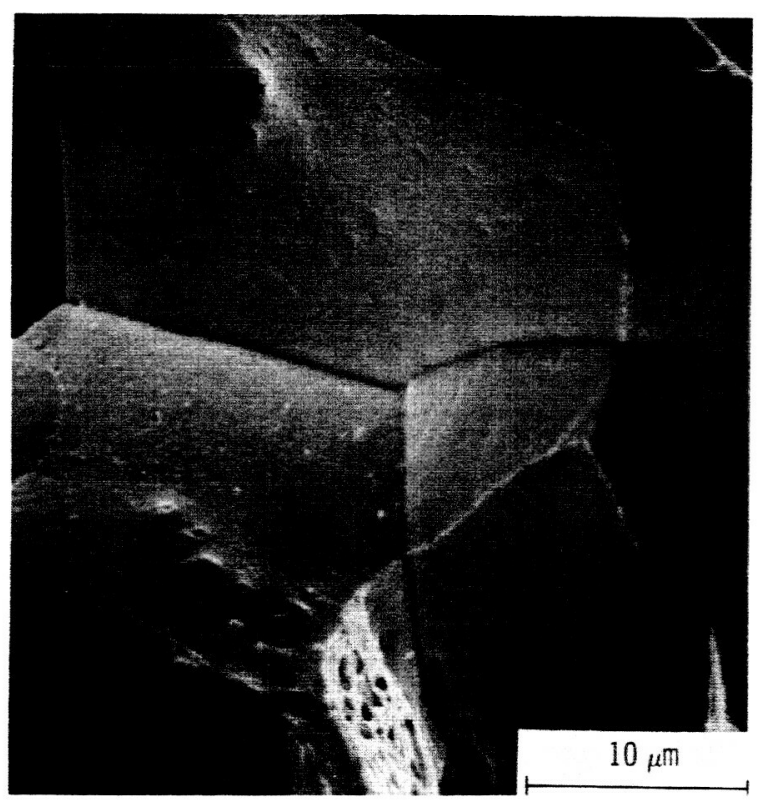

Figure 17. - Scanning electron micrographs of T-111 aged over the temperature range $925^{\circ}$ to $1150^{\circ} \mathrm{C}$ for 1000 hours. Hydrogen doped; bend tested at $25^{\circ} \mathrm{C}$. 